\title{
Microfacies and stable isotope analyses from the Carboniferous of the La Joya section in Sierra Agua Verde, Sonora, Mexico
}

\author{
Rafael Villanueva-Olea, Ricardo Barragán, Juan José Palafox-Reyes, José Carlos Jiménez-López, \\ Blanca E. Buitrón-Sánchez
}

Rafael Villanueva-Olea

rafael.villa@ciencias.unam.mx

Posgrado en Ciencias Biológicas, Universidad Nacional Autónoma de México. Av. Universidad 3000, Coyoacán, 04510, CDMX, Mexico.

\section{Ricardo Barragán}

Blanca E. Buitrón-Sánchez

Departamento de Paleontología, Instituto de Geología, Universidad Nacional Autónoma de México, Circuito de la Investigación Científica, Coyoacán, 04510, CDMX, Mexico.

\section{Juan José Palafox-Reyes}

Departamento de Geología, Universidad de Sonora, Boulevard Luis Encinas y Rosales s/n, Col. Centro, 83000, Hermosillo, Sonora, Mexico.

\section{José Garlos Jiménez-López}

Posgrado en Ciencias de la Tierra, Universidad Nacional Autónoma de México. Gd. Universitaria, 04510, Coyoacán, CDMX, Mexico.

BOL. SOC. GEOL. MEX. 2019

VOL. 71 NO. 3

P. $585-607$

http://dx.doi.org/10.18268/BSGM2019v71n3al

\begin{abstract}
In the Sierra Agua Verde in central-eastern Sonora, Mexico, a sequence of paleozoic rocks crops out, deposited in a carbonate platform environment with a marine biota consisting of phylloid algae, fusulinid foraminifera, Chaetetes sponges, tabulate corals, gastropods, bryozoans, brachiopods, and crinoids. In this region, a Mississippian-Pennsylvanian section, corresponding to the Santiago and La Joya formations, was studied to analyze the microfacies and reveal the paleoenvironmental evolution of the area. Nine facies associations were described, based on the composition and texture of the sample, and were linked to standard microfacies and facies zones according to the modified Wilson model. The section was analyzed for ${ }^{13} \mathrm{C}$ and ${ }^{18} \mathrm{O}$ stable isotopes, which revealed a series of excursions that can be related both to a global or regional-local scale events, as well as with the defined facies belts. The results indicate the section was deposited in a series of marine environments including reefal margin, sand banks, and open and restricted lagoons. The $\mathrm{C}$ and $\mathrm{O}$ positive excursions might be related to marine regression events, which are product of glacial episodes. Such events characterized important time intervals during the Late Paleozoic. Also, the carbon and oxygen excursions are related, to an influx of waters proceeding from the continent that partially masked the $\delta^{13} \mathrm{C}$ and $\delta^{18} \mathrm{O}$ global excursion patterns. The study is relevant as it is pioneer in analyzing stable isotope excursions for Sonora, and opens a window to more exhaustive research about the excursion patterns that could be related to global climate changes in a region with abundant Upper Paleozoic outcrops in Mexico.
\end{abstract}

Keywords: Mississippian, Pennsylvanian, Mexico, stable isotope analysis, microfacies, paleoenvironments.

\section{RESUMEN}

En la Sierra Agua Verde en el centro-este de Sonora, México, aflora una secuencia de rocas paleozoicas que se depositaron en un ambiente de plataforma carbonatada con una biota marina consistente en algas filoides, foraminiferos fusulinidos, esponjas del género Chaetetes, corales tabulados, gasterópodos, briozoarios, braquiópodos y crinoideos. En esta región, se estudió una sección del Misisípico-Pensilvánico, correspondiente a las formaciones Santiago y La Joya, con el objetivo de analizar las microfacies y revelar la evolución paleoambiental de la zona. Se describieron nueve asociaciones de facies caracterizadas por su composición y textura, y se vincularon a una serie de microfacies estándar y zonas de facies de acuerdo al modelo de Wilson. La sección también fue considerada para el estudio de isótopos estables de ${ }^{13} \mathrm{C} y$ ${ }^{18} \mathrm{O}$ que revelaron excursiones las cuales, en algunos casos, pueden ser asociadas a una serie de eventos a escala global, y en otros, a escala regional o local; estos eventos, además, se corresponden con los cinturones de facies definidos. Los resultados obtenidos indican que la sección se depositó en una serie de ambientes marinos que incluven el margen arrecifal, los bancos de arena y las lagunas con circulación abierta y restringida. Las excursiones positivas de carbono y oxígeno se relacionan con eventos de regresión marina producto de eventos glaciales que caracterizaron intervalos importantes del Paleozoico Tardío, así como a un influjo de aguas procedentes del continente que parcialmente enmascararon los patrones de excursiones de $\delta^{13} C y$ $\delta^{18} \mathrm{O}$ globales. El estudio resulta relevante pues es el primero en analizar las excursiones de isótopos estables de estas edades en el estado de Sonora y abre el campo a una investigación exhaustiva sobre los patrones de excursiones que se puedan relacionar con cambios en el clima a nivel global en un área rica en afloramientos del Paleozoico Superior en México.

Palabras clave: Misisípico, Pensilvánico, México, análisis de isótopos estables, microfacies, paleoambientes. 


\section{Introduction}

The microfacies analysis has been demonstrated as an important tool to interpret ancient environments (Ekdale et al., 1976; Kietzmann et al., 2008; Coronado and Rodriguez, 2009; Flügel, 2010; Liu et al., 2015; among others). By using the concept of standard microfacies developed by Flügel (1972) to categorize platform and reef carbonates it is possible to recognize the different types of facies zones defined by Wilson (1975), which allow us to allocate carbonate sediments in a particular paleoenvironment according to paleontological and textural criteria.

The Sierra Agua Verde, located in the state of Sonora in northern Mexico, $110 \mathrm{~km} \mathrm{E} \mathrm{of} \mathrm{Her-}$ mosillo city (Figure 1), is an area that has been poorly studied with regard to microfacies and geochemical analyses. This mountain range, distinguished for its Paleozoic fossil richness, contains rocks of the Agua Verde Group, a carbonate-platform sequence of Ordovician-Lower Permian age (Ochoa-Granillo and Sosa-León, 1993). The fossil biota found is diverse; however, few studies have been published. Gómez-Espinosa et al. (2008) reported the presence of fusulinids and calcareous algae; Buitrón-Sánchez et al. (2007) indicated the existence of a fossil association of phylloid algae, fusulinids, chaetetids, tabulate corals, gastropods, fenestellid bryozoans, productid and spiriferid brachiopods, crinoids, and conodonts in fossiliferous limestones belonging to the La Joya formation.

Several contributions have also improved the knowledge of the stratigraphy of the area: Stewart et al. $(1984,1988,1999)$ were the first to recognize the presence of Paleozoic rocks in the area; Minjarez-Sosa et al. (1993) and Ochoa-Granillo and Sosa-León (1993) described Ordovician, Devonian, Mississipian, Pennsylvanian, and Permian strata. Other important studies that contributed to the understanding of the stratigraphy of the region include those of Repetsky et al. (1985), Gehrels et al. (1995), and Poole et al. (1995).

Ochoa-Granillo and Sosa-León (1993) inferred the depositional environment of the La Joya forma- tion as a shallow platform, with the development of calcareous banks with terrigenous input. Buitrón-Sánchez et al. (2007) concluded that the fossiliferous association of this unit is typical of tropical shallow seas and shows a strong affinity with species of regions from the south of the United States and the Midcontinent area. However, AlmazánVázquez et al. (2007) pointed out that the La Joya formation was deposited in a relatively deep-water environment, on the boundary with the photic zone, because of a lack of shallow-water proxies (i.e., algae), and an abundance of crinoids, bryozoans, and brachiopods, interpreted by those authors as indicators of deeper water. On the other hand, Gómez-Espinosa (2010) characterized 12 different microfacies, from base to top, as slope, lagoon, slope, toe of slope, lagoon, slope, lagoon, and reef. Both studies are sustained on a reduced number of samples, which impedes a determinant conclusion. Recently Navas-Parejo et al. (2017) reported different biozones of conodonts in La Joya, and thus defined the ages for this section.

The aim of this work is to unravel the variations among depositional environments within the Carboniferous La Joya section in Sierra Agua Verde. The above by means of a more detailed sampling on that area that allows recognition of variations of petrographic elements through a microfacies analysis. Additionally, ${ }^{13} \mathrm{C}$ and ${ }^{18} \mathrm{O}$ stable isotope curves were analyzed, and their excursion patterns matched with facies associations, bringing some insight in global to regional conditions present during the deposition time of the La Joya sediments.

\section{Stratigraphy}

\subsection{SIERRA AGUA VERDE STRATIGRAPHY}

In Sierra Agua Verde (Figure 2), Paleozoic rocks are well exposed in outcrops belonging to the Cambrian San José Group and to the Ordovician-Lower Permian Agua Verde Group. The La Joya and Santiago formations, defined by Ochoa-Granillo and Sosa-León (1993), represent 

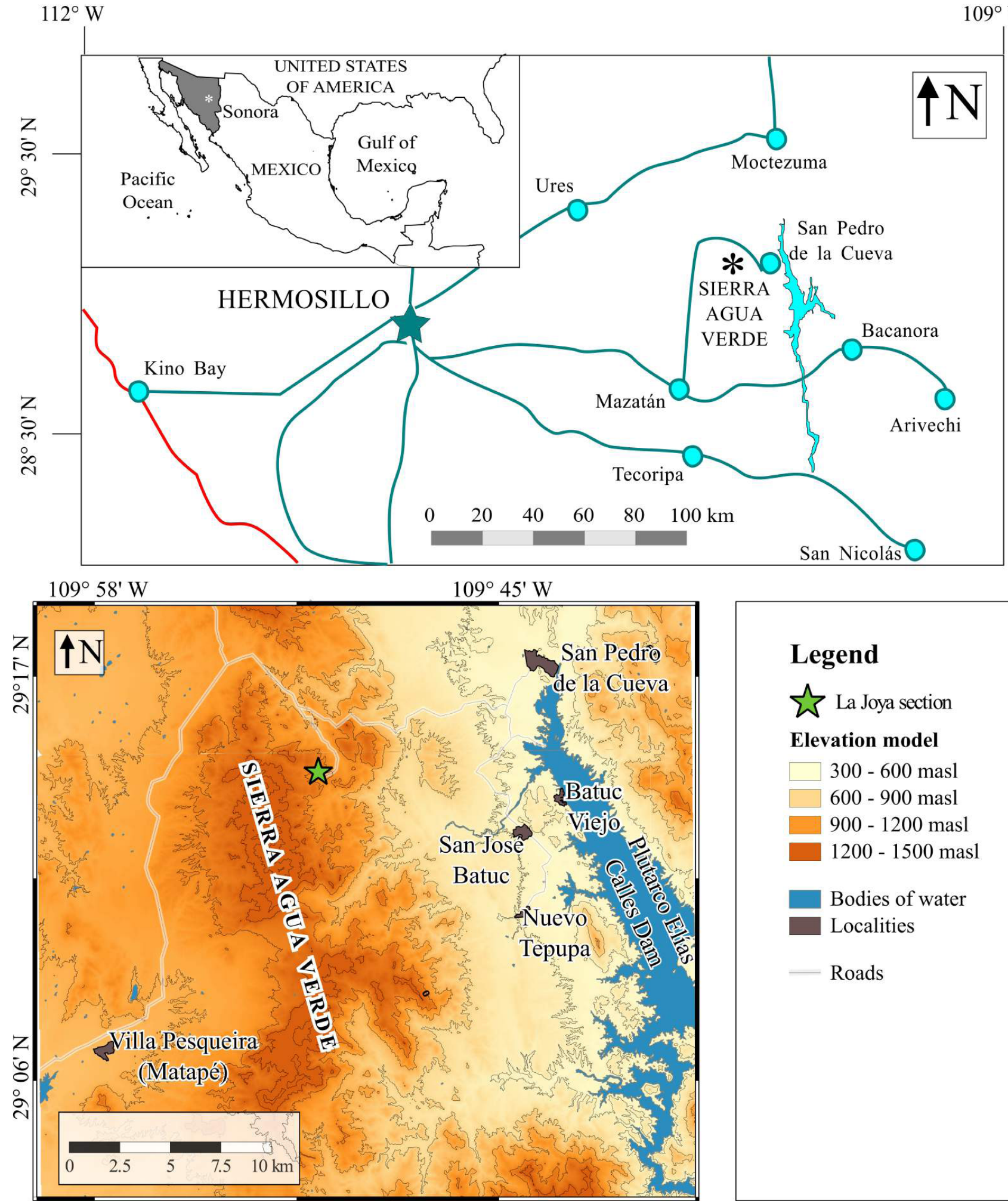

\section{Legend}

$\sum$ La Joya section

\section{Elevation model}

300 - 600 masl

600 - 900 masl

900 - 1200 masl

1200 - 1500 masl

Bodies of water

Localities

Roads

Figure 1 (A) Map of Mexico showing the location of the studied section in Sierra Agua Verde and the state of Sonora. (B) Topographic map of the Sierra Aqua Verde. 
informal lithostratigraphic units with a thickness of $669 \mathrm{~m}$ that belong to the Agua Verde Group.

The Santiago formation consists of limestones, dolomitized and sandy limestones, and sandstones. The lower part of the formation corresponds to dolomitized gray limestone, intercalated with small horizons of sandstone and $14 \mathrm{~cm}$ thick, black chert beds as well. The middle part is composed of sandy limestone and calcareous shale rich in corals, brachiopods, bryozoans, and bivalves.
The upper part of this unit is represented by gray fossiliferous limestone with some black chert lenses, and grades into red shale-sandstone with Syringopora (Ochoa-Granillo and Sosa-León, 1993). According to Ochoa-Granillo and Sosa-León (1993), the Santiago formation was deposited in a platform with development of calcareous banks of colonial organisms and is coetaneous with the Escabrosa and Horquilla formations in the Cabullona area, northeast of Sonora.

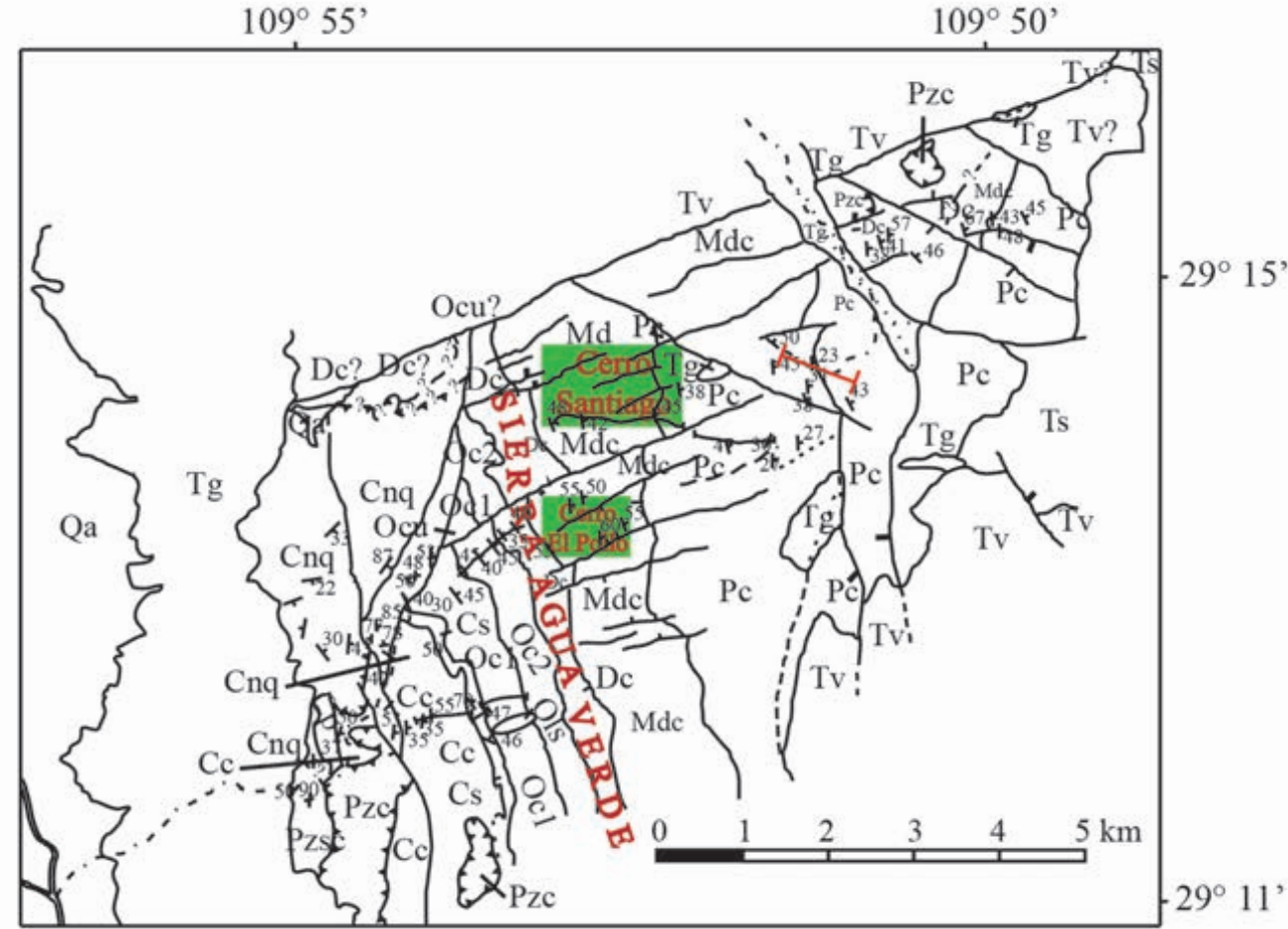

Qa: Quaternary alluvial deposits

Q1s: Quaternary landslide deposits

Tg: Tertiary gravel deposits

Ts: Tertiary sandstone, siltstone, and limestone

Tv: Tertiary volcanic rocks

Pzc: Undated (Paleozoic?) limestone

Pzsc: Undated (Paleozoic?) siltstone and limestone

Pc: Pennsylvanian ledge- and slope-forming carbonate unit

Mdc: Upper Devonian and Mississippian cliff-forming carbonate

unit

Dc: Upper Devonian carbonate and siliciclastic unit

Oc1: Lower Ordovician carbonate unit 1

Oc2: Lower Ordovician carbonate unit 2

Ocu: Undivided Lower Ordovician carbonate units 1 and 2

Cs: Upper Cambrian silstone unit

Cc: Middle? and Upper Cambrian carbonate unit

Cp: Lower Cambrian Proveedora Quartzite

Cnq: Neoproterozoic? and Lower Cambrian quartzite, siltstone, and dolostone unit 
This formation underlies and is transitional to the La Joya formation, which has a thickness of $294 \mathrm{~m}$ consisting of limestone intercalated with calcareous lodolites and sandy lenses. The base of the La Joya formation is composed of medium to thick, massive, light gray to reddish limestone strata, with small calcareous lodolite intercalations in thinner strata, with black to red chert nodules embedded. Common fossils are the coral Syringopora (middle Silurian-Pennsylvanian), the brachiopod Crurithyris (Devonian-Permian), the bryozoan Glyptopora (Carboniferous), and crinoidal remains.

Above these strata, we found light-gray limestone in fresh rock and blue-gray in weathered surface, with intercalations of calcareous reddish mudstones. The fossil fauna consists of Syringopora corals, crinoid plates, bryozoans, gastropods, and other shell remains.

At its upper part, it consists of medium-thick gray to reddish limestone strata, intercalated with calcareous red lodolite, and white to red chert nodules and lenses with small dark bands. Fossil fauna consists of the coralline sponge Chaetetes from the middle Pennsylvanian, the bryozoan Fenestrellina of Silurian-Permian age, and the Pennsylvanian-Permian brachiopod Neospirifer.

\subsection{LA JOYA SECTION}

A 270 m thick section of the La Joya (Pennsylvanian) and Santiago (Mississippian) formations was measured (Figure 3). The lithology of the section

Samples

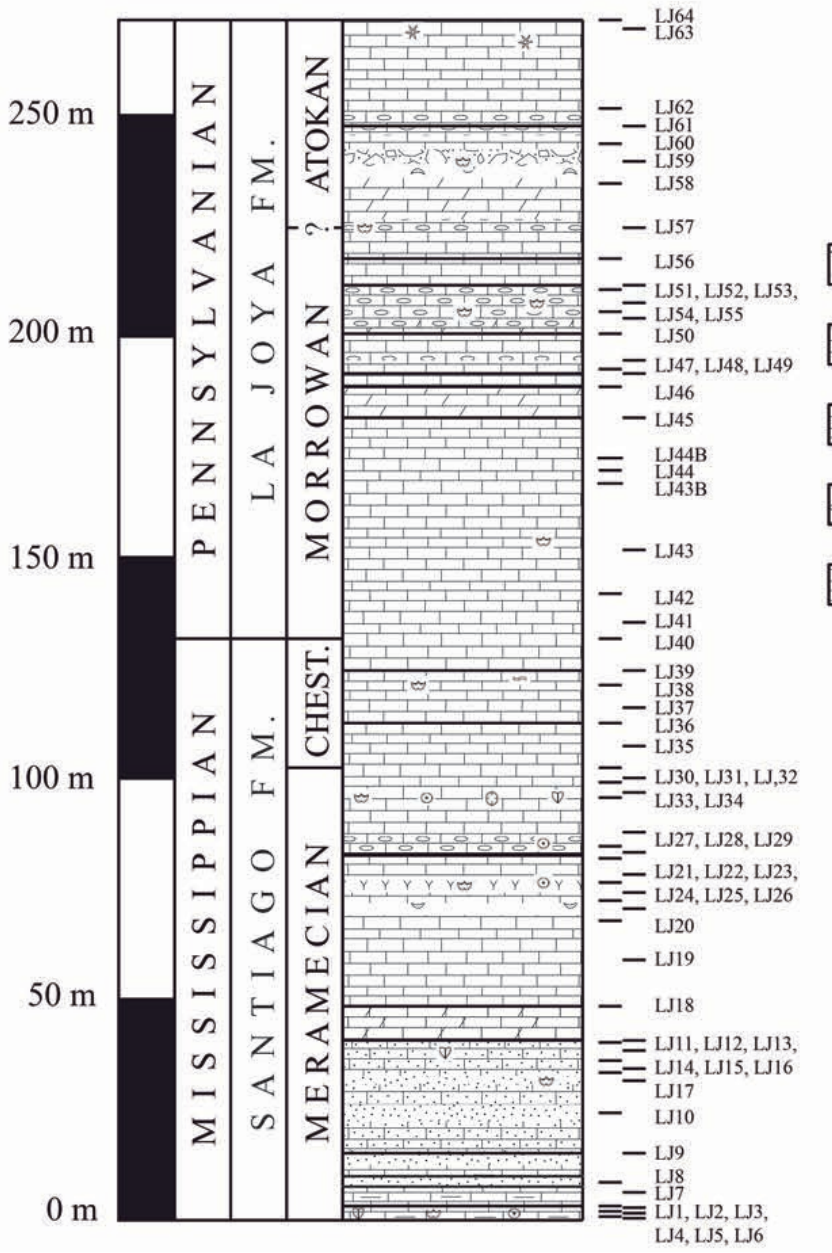

LITHOLOGY

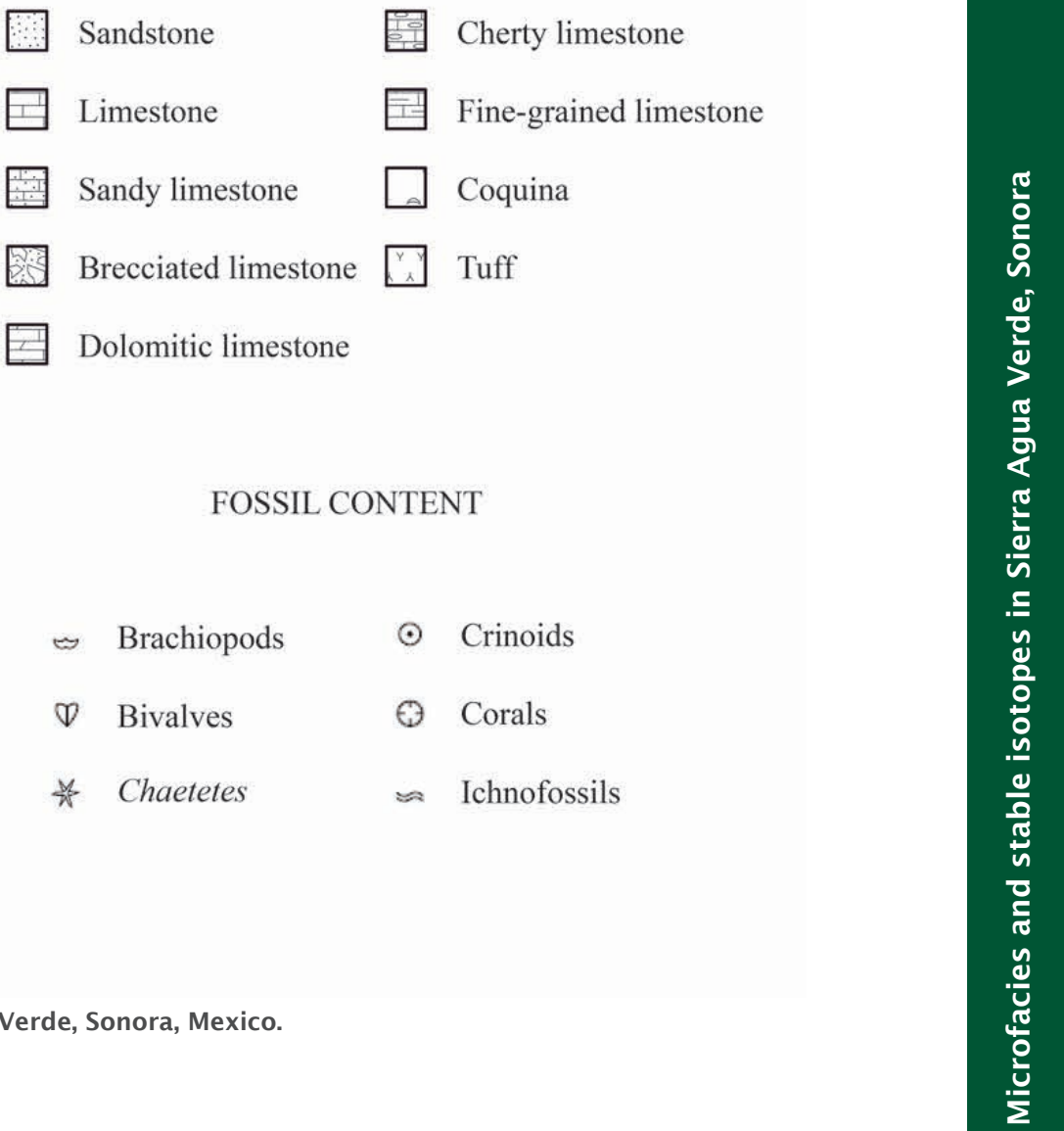


is mainly limestone. The $50 \mathrm{~m}$ interval at its base corresponds to sandy limestone intercalated with finer-grained limestone. The sandy limestone is overlain by poorly fossiliferous (crinoids, brachiopods, and bivalve shells) grayish limestone. Upwards, from 50 to $180 \mathrm{~m}$, a lithology of relatively homogeneous, light to dark gray limestone is observed. At $75 \mathrm{~m}$ above the base of the section, there is an intercalation of a thin layer of pale volcanic tuff. At $80 \mathrm{~m}$, a thin coquina layer, mainly composed of brachiopods, intercalates the limestone. From 180 to $270 \mathrm{~m}$, the limestone changes from grayish to pinkish colors with intercalations of white and dark chert nodules. At this level, crinoid fossils, brachiopods, and Chaetetes coralline sponges are exposed.

\section{Methods}

\subsection{IDENTIFICATION OF FAGIES ASSOGIATIONS AND ENVIRONMENTAL INTERPRETATION}

In order to achieve a paleoenvironmental reconnaissance of the La Joya section in the Sierra Agua Verde, a petrographic study of 67 samples was carried out. Classification of recognized facies followed the scheme of Dunham (1962), which considers textural and grain type components.

Samples were sectioned in duplicate, so that each sample had two thin sections perpendicularly oriented each other with the purpose of obtaining as much information as possible. The thin sections were observed in a petrographic microscope Olympus BX51 and pictures were taken using a CoolSNAP-Pro Color RS Photometrics camera, integrated to the microscope, with $2 \mathrm{x}, 4 \mathrm{x}$, and $10 \mathrm{x}$ objectives. For the image edition, the software Image-Pro Plus 7.0.0.591 of Media Cybernetics was used. Each sample was assigned to a standard microfacies (SMF) (Flügel, 2010). Those samples with similar SMF's, textures, and composition were related to a characteristic facies association. With the information gathered, the different facies zones were interpreted according to the model of Wilson (1975).

\section{2. $\delta^{13} \mathrm{C}$ AND $\delta^{18} \mathrm{O}$ STABLE ISOTOPE ANALYSES}

For oxygen and carbon isotope analysis, we surveyed bulk rock analysis, selecting those samples with minor diagenesis alteration, so that the obtained signals were those of the depositional environment. The selection of samples was further carried out by petrographic evaluation: thin sections with pervasive silicification, dolomitization, or recrystallization, as well as those with no evidence of the deposit facies, were excluded from isotopic analyses. The rock powder was obtained by drilling with a Dremel 4000 in the rock matrix, avoiding areas of recrystallization, stylolites, and calcite veins.

To determine the compositions of bulk rock carbonate samples, the method designed by McCrea (1950) was used. Briefly, this method consists of measuring ${ }^{13} \mathrm{C} /{ }^{12} \mathrm{C}$ and ${ }^{18} \mathrm{O} /{ }^{16} \mathrm{O}$ ratios of $\mathrm{CO}_{2}$ released from a reaction with $\mathrm{H}_{3} \mathrm{PO}_{4} 100 \%$ at 25 ${ }^{\circ} \mathrm{C}$ during 54 hours in a Thermo Finnigan MAT 253 mass spectrometer at the Stable Isotope Laboratory of the Institute of Geology, UNAM.

$\delta^{13} \mathrm{C}$ values were measured and expressed relative to the VPDB (Vienna Pee Dee Belemnite) scale, normalized using consensus values of $-46.6 \%$ for LSVEC $\left(\mathrm{LiCO}_{3}\right)$ and + 1.95\% for NBS 19 (Coplen et al., 2006). $\delta^{18} \mathrm{O}$ values were also measured relative to VPDB, normalized according to Coplen (1988). However, in order to have better comparisons with regard to the literature, $\delta^{18} \mathrm{O}$ VPDB scale was converted to VSMOW scale following the equation:

$$
\delta^{18} \mathrm{O}_{\text {X/VSMOW }}=\left(1.03091 \times \delta^{18} \mathrm{O}_{\mathrm{X} / \text { VPDB }}\right)+30.91
$$

where $\delta^{18} \mathrm{O}_{\mathrm{x} / \text { vsmow }}$ is the $\delta^{18} \mathrm{O}$ value in the sample $\mathrm{x}$ in VSMOW scale, whereas $\delta^{18} \mathrm{O}_{\mathrm{X} / \mathrm{VPDB}}$ is the $\delta^{18} \mathrm{O}$ value of the same sample in VPDB scale. The analyses were performed using the reference materials LSVEC, NBS-19, and NBS-18, and every 7 samples, an internal $\mathrm{CaCO}_{3}$ Sigma reference was placed to verify repeatability and reproducibility less than $0.2 \%$. 


\section{Results}

\subsection{MICROFACIES ANALYSIS}

Nine facies associations (FA) were defined based on textural and compositional features, and were placed in some of the facies zones (FZ) proposed by Wilson (1975) and modified by Schlager (2002). FA1. Grainstone/rudstone with abundant crinoids (Figure 4). This facies is characterized by fragmented brachiopod and bivalve shells, as well as scarce bryozoans and ostracods. Sparsely, it displays some ooids and benthic foraminifera. FZ5: platform-margin reef.

FA2. Packstone of pellets/peloids (Figure 5). Samples with abundant pellets/peloids and sand grains with fauna consisting of crinoids, foraminifera, and sponge spicules. On this association, crinoids are not as abundant as in FA1. Due to the presence of sponge spicules and a great quantity of pellets, FA2 is interpreted as belonging to a restricted lagoon in the platform (FZ8). The presence of terrigenous material indicates a proximity to the land; the good sorting indicates a local reworking. FA3. Grainstone with coated bioclasts and peloids (Figure 6). As in FA2, peloids are a very important component, and cortoids made up of bioclasts coated by micritic layers are also significant. Algae, benthic foraminifera, and crinoids are common, whereas ooids and Girvanella oncoids are rare. FZ6: sand banks on platform margin with constant wave action, at or above the fair-weather wave base.

FA4. Wackestone/floatstone of sponge spicules and fragmented and disarticulated remains of crinoids, brachiopods, and ostracods (Figure 7). Typical facies of slope and lagoonal environments with mud-supported textures and elements proceeding

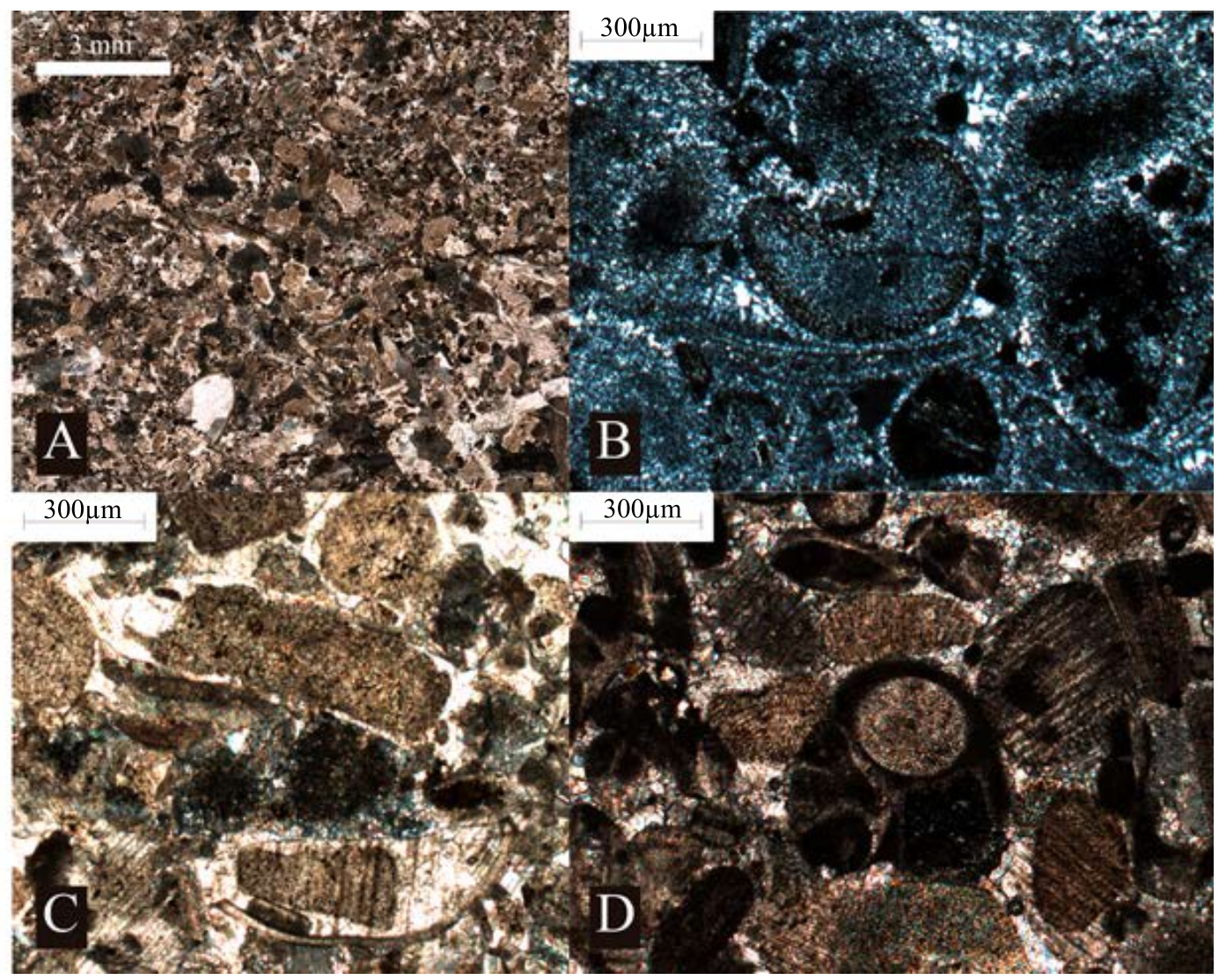

Figure 4 FA1: Grainstone/rudstone with abundant crinoids. (A) Sample LJ 4, reconstruction after 2x images; (B) sample LJ 10; (C) sample LJ 15; (D) sample LJ 36. 


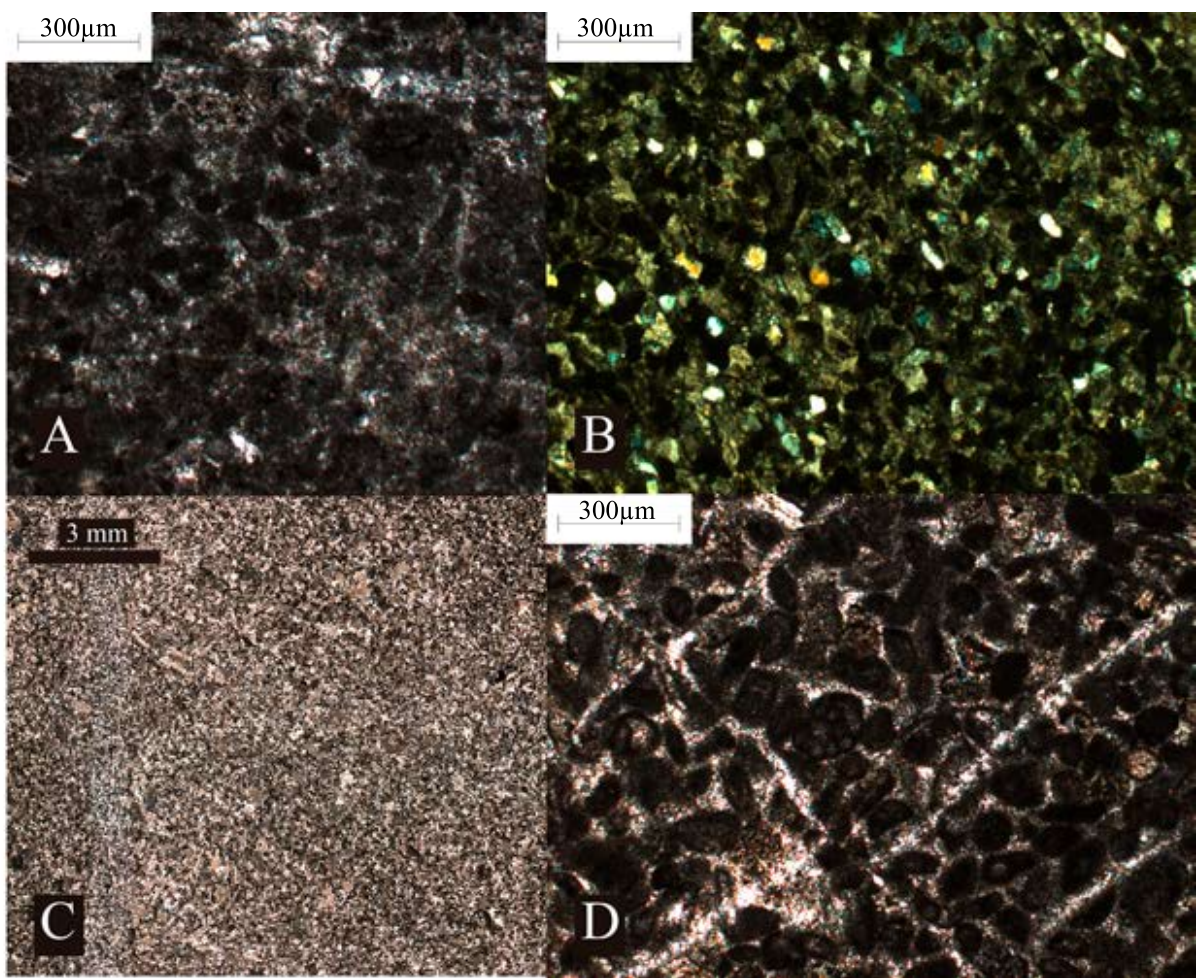

Figure 5 FA2: Packstone of pellets/peloids. (A) Sample LJ 8; (B) sample LJ 31; (C) sample LJ 34, reconstruction after 2x images; (D) sample LJ 64.

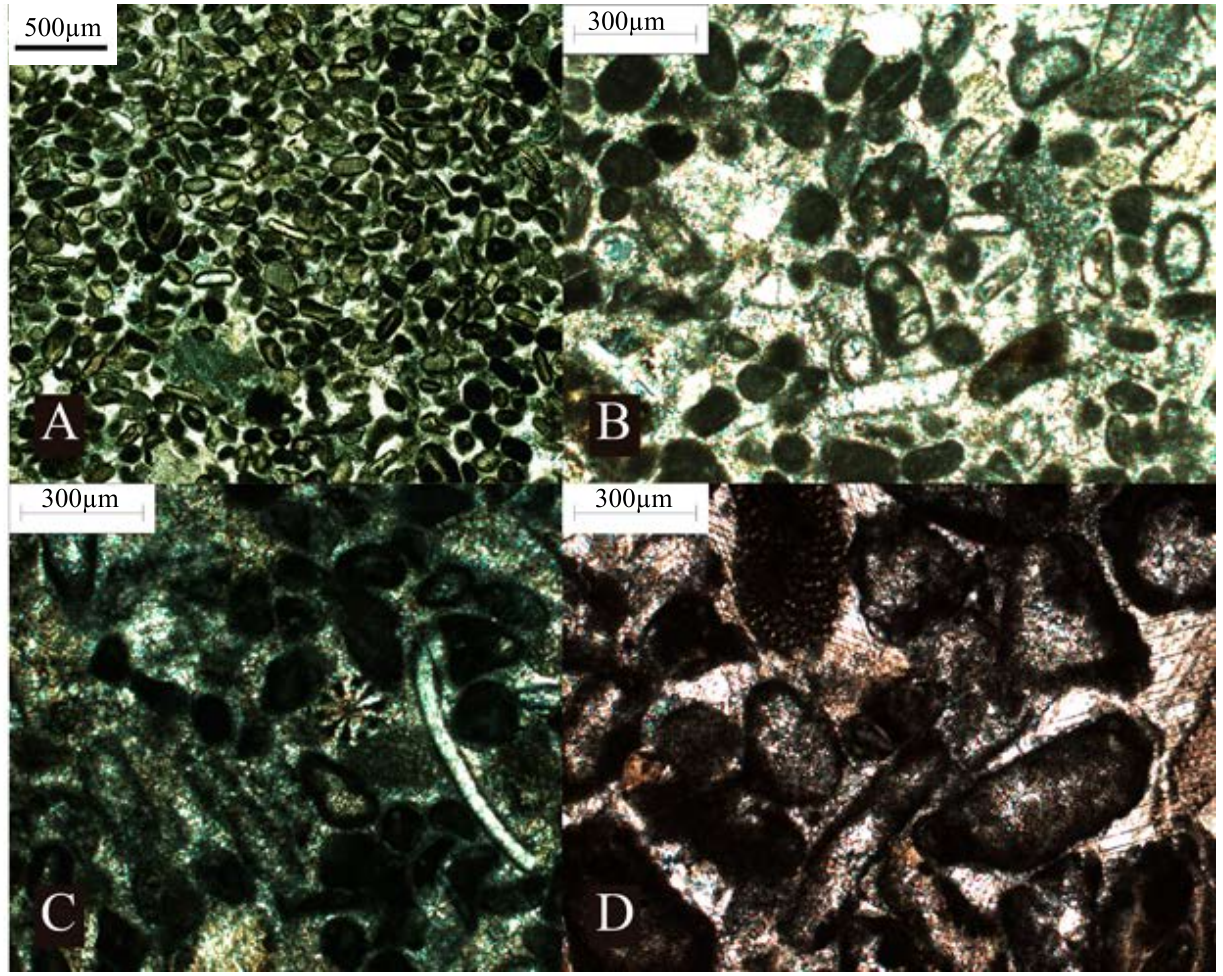

Figure 6 FA3: Grainstone with coated bioclasts and peloids. (A) Sample LJ 3, reconstruction after 4x images; (B) sample LJ 41; (C) sample LJ 42; (D) sample LJ 52. 
from the reefal crest and the platform margin, that fall down into the slope (fore reef position) or into the lagoon (back reef position), such as crinoid and brachiopod remains, as well as lithoclasts in a brecciated fabric. FA4 is interpreted as a lagoon with open circulation (FZ7) because of a lack of evidence of slope environments in neighbor microfacies.

FA5. Grainstone/rudstone and floatstone with lagoonal fossils (Figure 8). Facies with crinoids and brachiopods, as well as typical fauna from lagoonal environments, such as foraminifera, bryozoans, bivalves, gastropods, and echinoids. Also, non-skeletal elements as cortoids and intraclasts are found. Unlike FA1, this association is rich in textures with wackestone/floatstone type, meaning that they are poorly washed due to the position in a lagoon with lower wave influence. The important occurrence of foraminifera allows allocating this association in the FZ7 (open marine lagoon).
FA6. Grainstone with crinoids and pellets (Figure 9). In contrast to FA1, this association contains crinoids surrounded by pellets, with a higher amount of micritic mud. It is considered intermediate between FA1 and FA2, for it does not contain as much crinoids as FA1, nor as much pellets as FA2. Sponge spicules are present in some samples of this association. FZ5: platform reefal margin.

FA7. Packstone/grainstone with abundant benthic foraminifera and algae (Figure 10). Some of the foraminifers seem abraded and broken, which indicates they underwent some transport from high-energy to low-energy environments in an open-circulation lagoon (FZ7).

FA8. Mudstone/wackestone with scarce fossil content (Figure 11). Facies with small quantities of fossils corresponding to sponge spicules and crinoids, and trace elements of ostracods. Some samples have diagenetic alteration (i.e. dolomitization and silicification), although this does not prevent

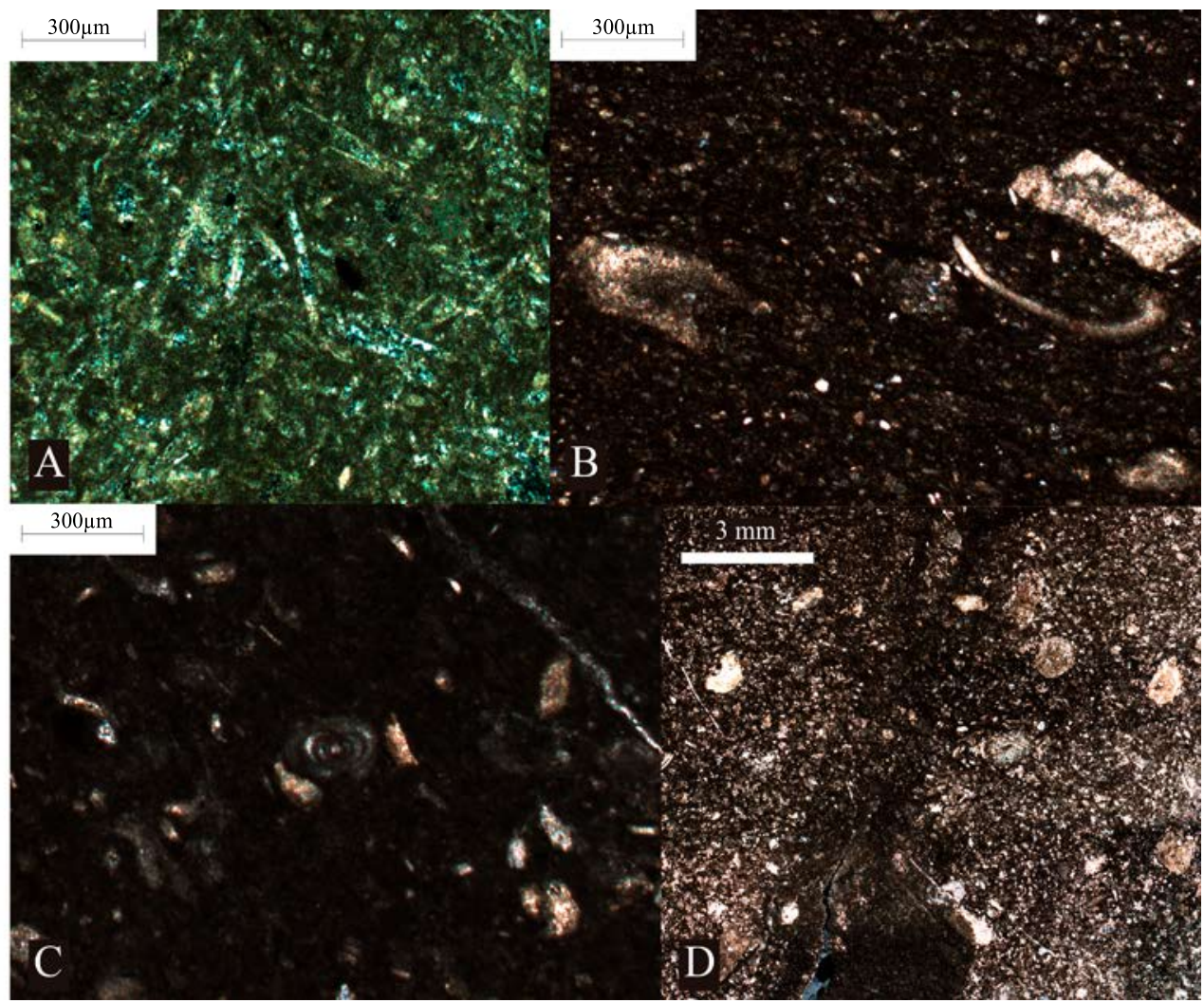

Figure 7 FA4: Wackestone/floatstone of sponge spicules and fragmented and disarticulated remains of crinoids, brachiopods, and ostracods. (A) Sample LJ 30; (B) sample LJ 47; (C) sample LJ 48; (D) sample LJ 49, reconstruction after 2x images. 


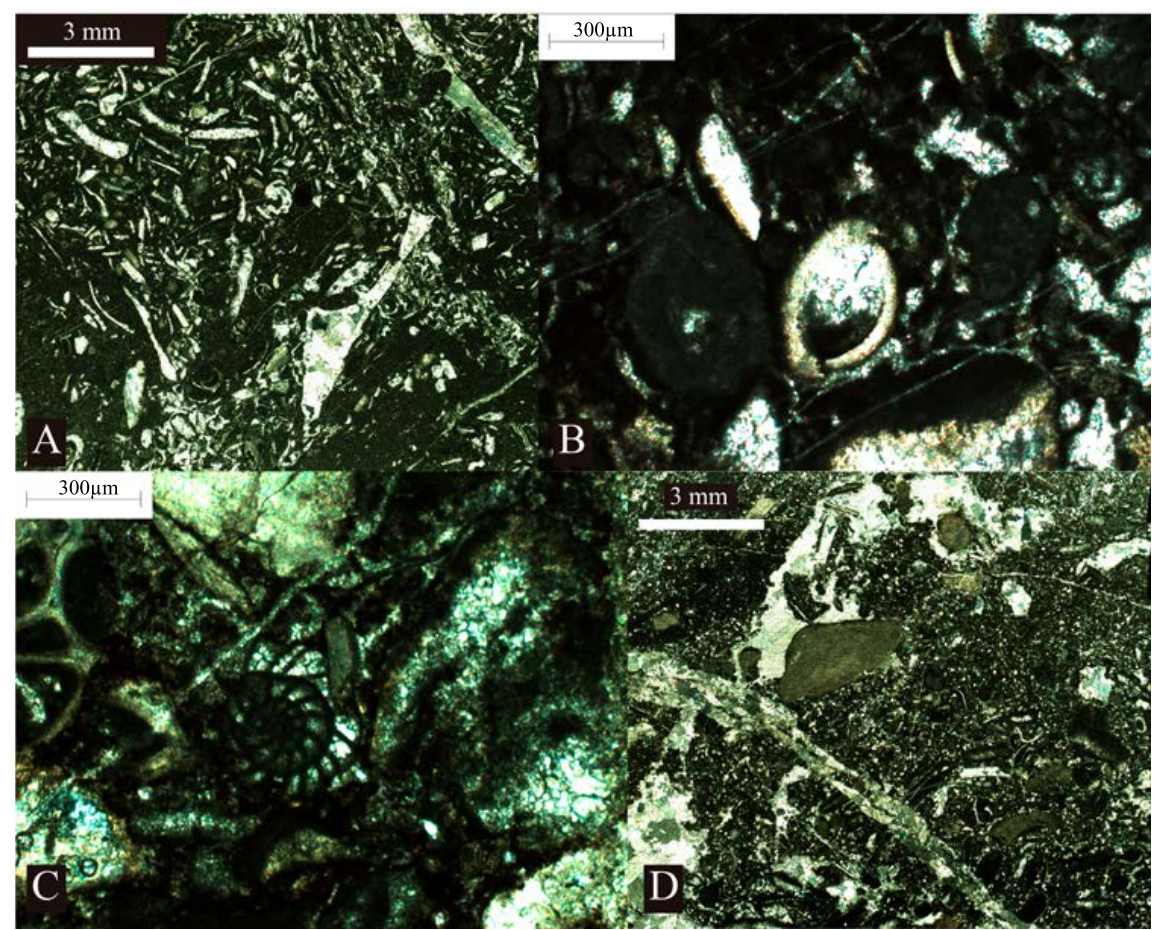

Figure 8 FA5: Grainstone/rudstone and floatstone with lagoonal fossils. (A) Sample LJ 54; (B) sample LJ 56; (C) sample LJ 57; (D) sample LJ 62, reconstruction after $2 x$ images.

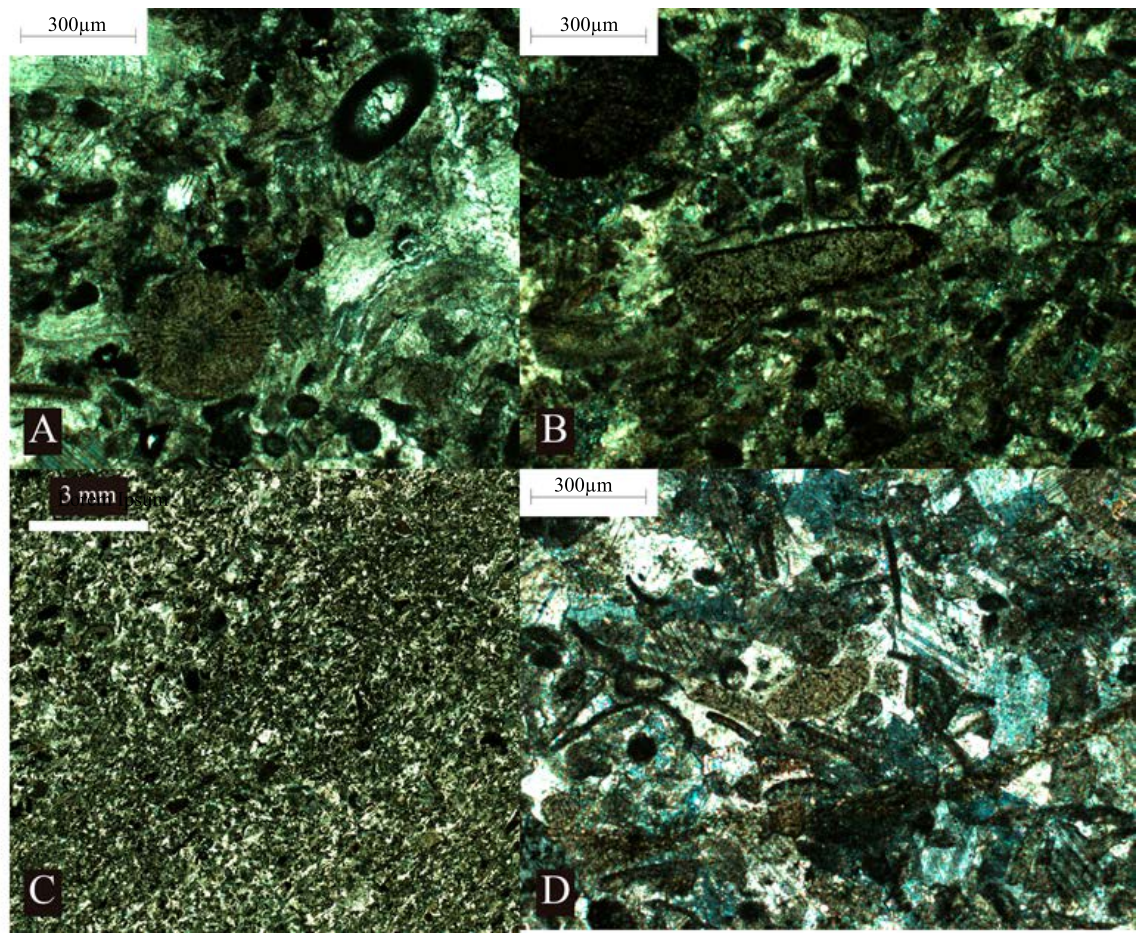

Figure 9 FA6: Grainstone with crinoids and pellets. (A) Sample LJ 5; (B) sample LJ 11; (C) sample LJ 11, reconstruction after 2x images; (D) sample LJ 12. 


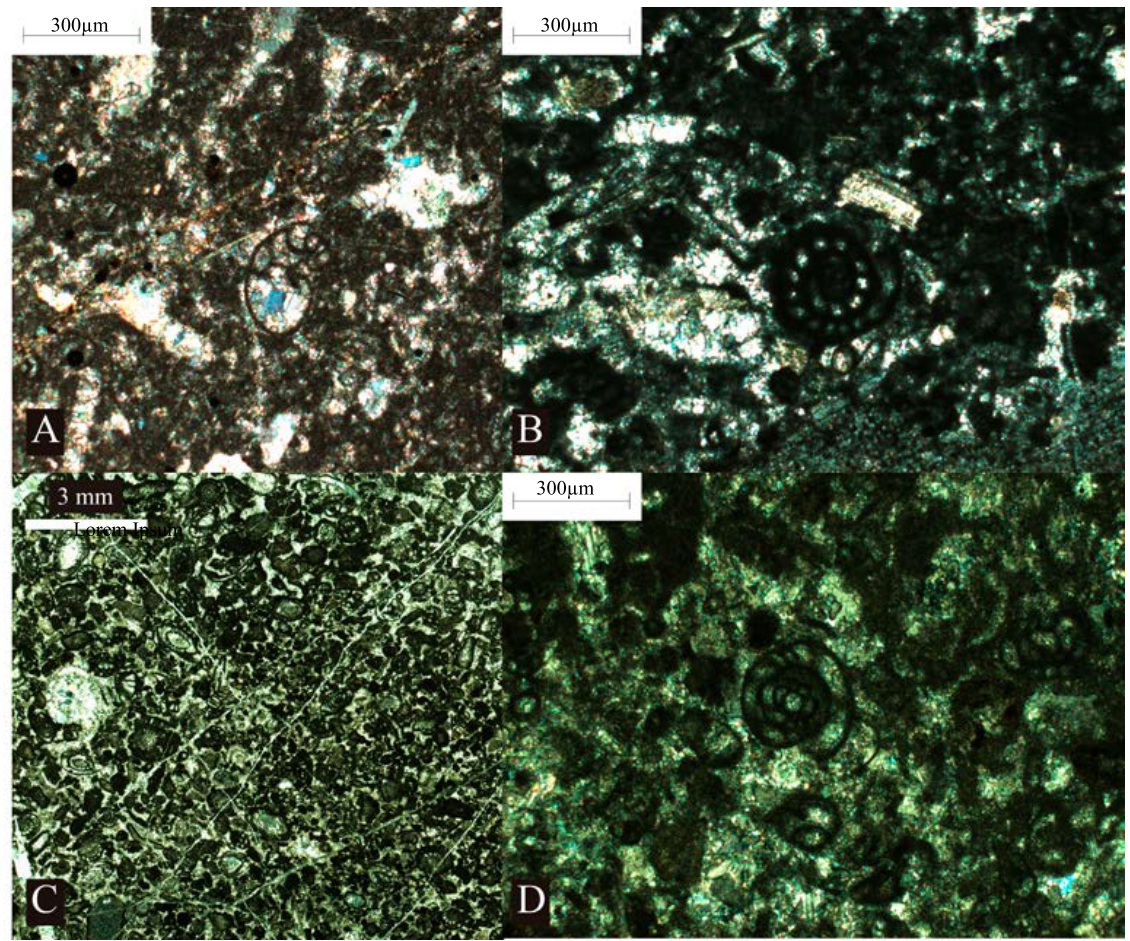

Figure 10 FA7: Packstone/grainstone with abundant benthic foraminifera and algae. (A) Sample LJ 43B; (B) sample LJ 44; (C) sample LJ 63 , reconstruction after $2 x$ images; (D) sample $L J 63$ bis.

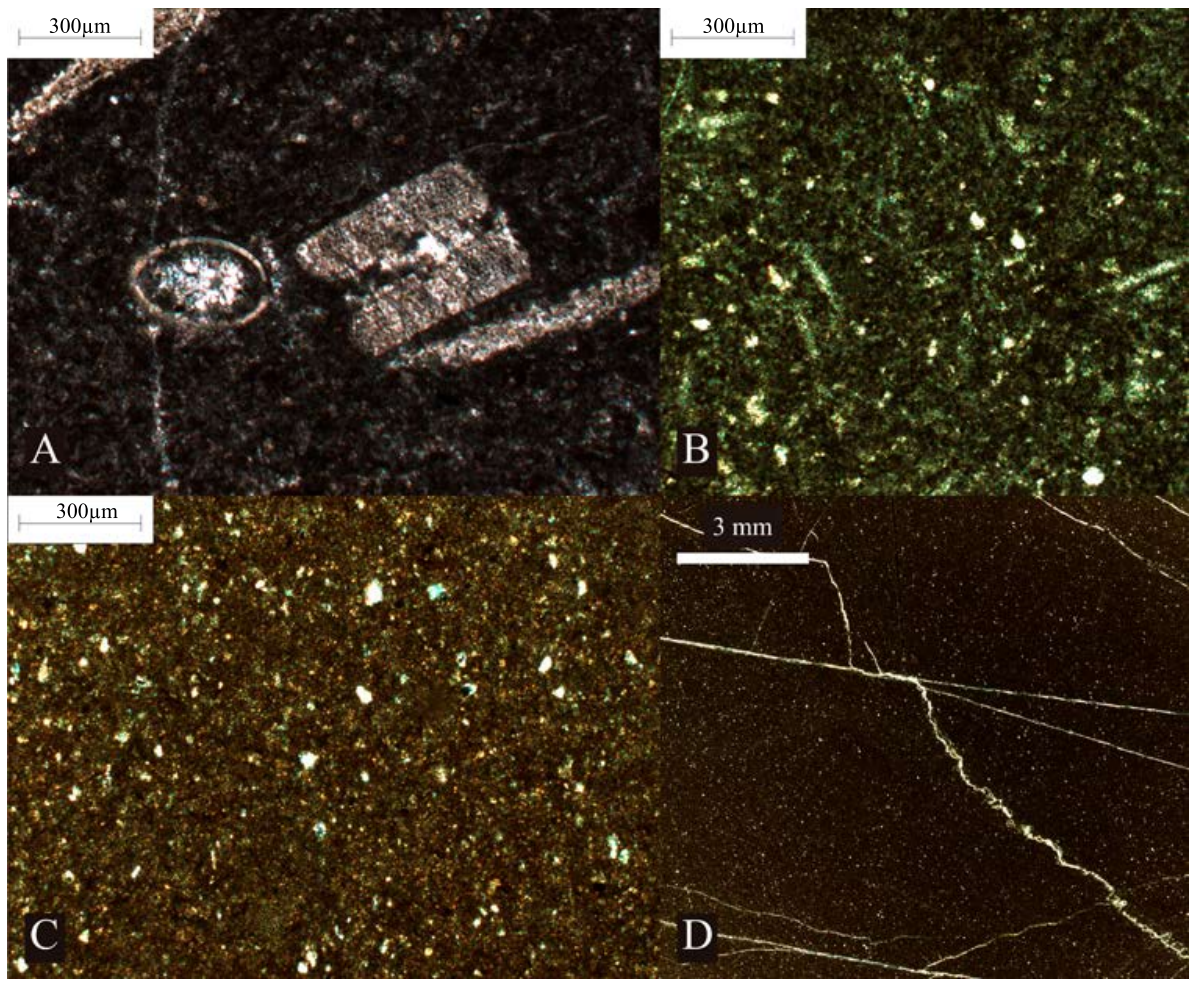

Figure 11 FA8: Mudstone/wackestone with scarce fossil content. (A) Sample LJ 51; (B) sample LJ 55; (C) sample LJ 6; (D) sample LJ 60, reconstruction after $2 x$ images. 
the recognition of deposit facies. It is associated with SMF 1 "spiculite wackestone/packstone" due to the presence of sponge spicules, and with SMF 23 "Non-laminated homogenous micrite or micro-sparite without fossils" due to mud-supported texture without fossils. Although SMF 1 is typical of deep environments, it is also found in protected shallow platform environments (Flügel, 2010). FZ8: restricted-circulation lagoon.

FA9. Laminated peloidal bindstone (Figure 12). This FA is assigned to the SMF 16-L because of the presence of micritic laminae composed of mud peloids. In addition, sand grains from land erosion, as well as some intraclasts, are common elements. This facies appears as pelsparite laminae alternating with pelmicrite laminae of microbial origin, with peloids spreading out fully and homogeneously. FZ8: restricted-circulation lagoon.

\subsection{STABLE ISOTOPE ANALYSIS}

The values obtained for the analysis of ${ }^{13} \mathrm{C} /{ }^{12} \mathrm{C}$ and ${ }^{18} \mathrm{O} /{ }^{16} \mathrm{O}$ ratios are given in Appendix 1. The corresponding curves (Figure 13) are compared with the distribution of the different facies associations and Wilson's (1975) facies belts throughout

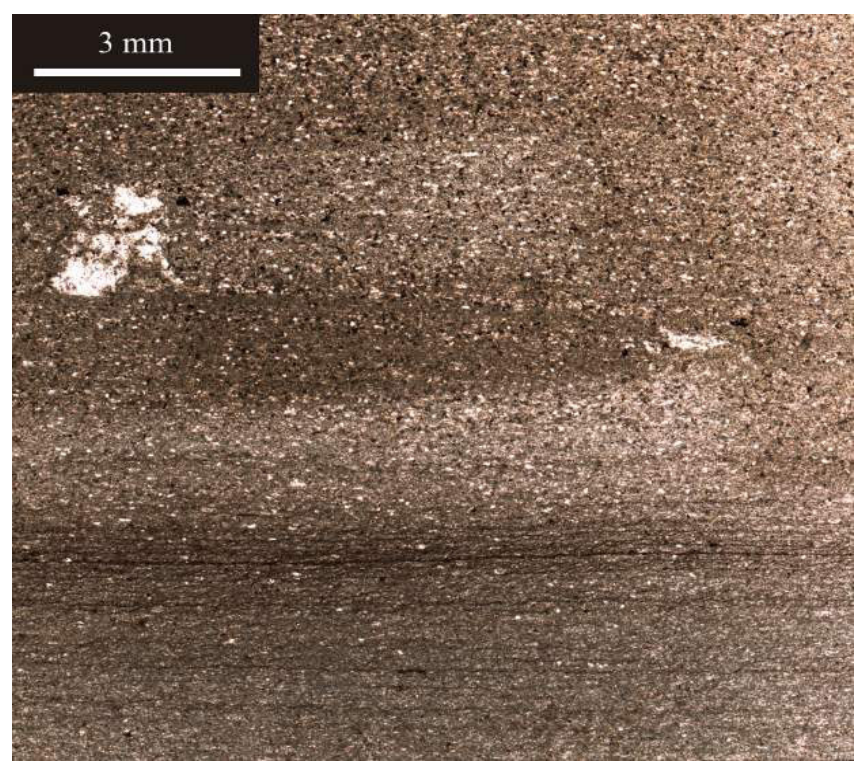

Figure 12 FA9: Laminated peloidal bindstone. Sample LJ 39; reconstruction after $2 x$ images. the stratigraphic section, which are considered paleobathymetrical indicators.

At the base of the section, in the Meramecian stage, $\delta^{13} \mathrm{C}$ values range from 1 to $4 \%$ except for two peaks that lower the $\delta^{13} \mathrm{C}$ to less than $-1.49 \%$ and $-2.85 \%$. After those negative excursions, values recover up to 2 to $3 \%$. The Chesterian stage starts with a $\delta^{13} \mathrm{C}$ of $1.35 \%$ and henceforth, values do not change significantly. At the beginning of Morrowan stage, $\delta^{13} \mathrm{C}$ decreases from $0.39 \%$ to $-1.75 \%$ and it recovers until reaching a peak of $1.2 \%$, after which levels decrease to $-2.04 \%$, a little before the tentative Morrowan-Atokan boundary at the upper part of the section. In the presumable Atokan, values increase to $1.48 \%$. These values are lower than those calculated in other Carboniferous localities (Brand, 1989; Mii et al., 1999; Veizer et al., 1999; Saltzman, 2005).

With regard to $\delta^{18} \mathrm{O}$ values, some abrupt changes can be observed at the base of the section, being the most abrupt of all, that of the 21.3 to $15.2 \%$ from sample LJ 4 to LJ 5. After that, the tendency is a recovering of values that reached almost 25\%o during the Meramecian. A little negative excursion continues and, by the end of the Meramecian, a new raising in $\delta^{18} \mathrm{O}$ values can be observed. For the Chesterian, the tendency is a lowering of the values whose minimum level extended into the lowermost Morrowan (Lower Pennsylvanian) with values around $17 \%$. This negative excursion is followed by a positive one with changing values but which, ultimately, brought the curve until a maximum value of $25 \%$. At the presumable Atokan, $\delta^{18} \mathrm{O}$ values changed more abruptly but, in any case, they were still high.

\section{Discussion}

Examining the paleobathymetric curve based on microfacies analysis (Figure 13), we interpret the Mississippian strata to have been deposited in offshore areas, nearby the platform margin. This can be confirmed with the high frequency of 


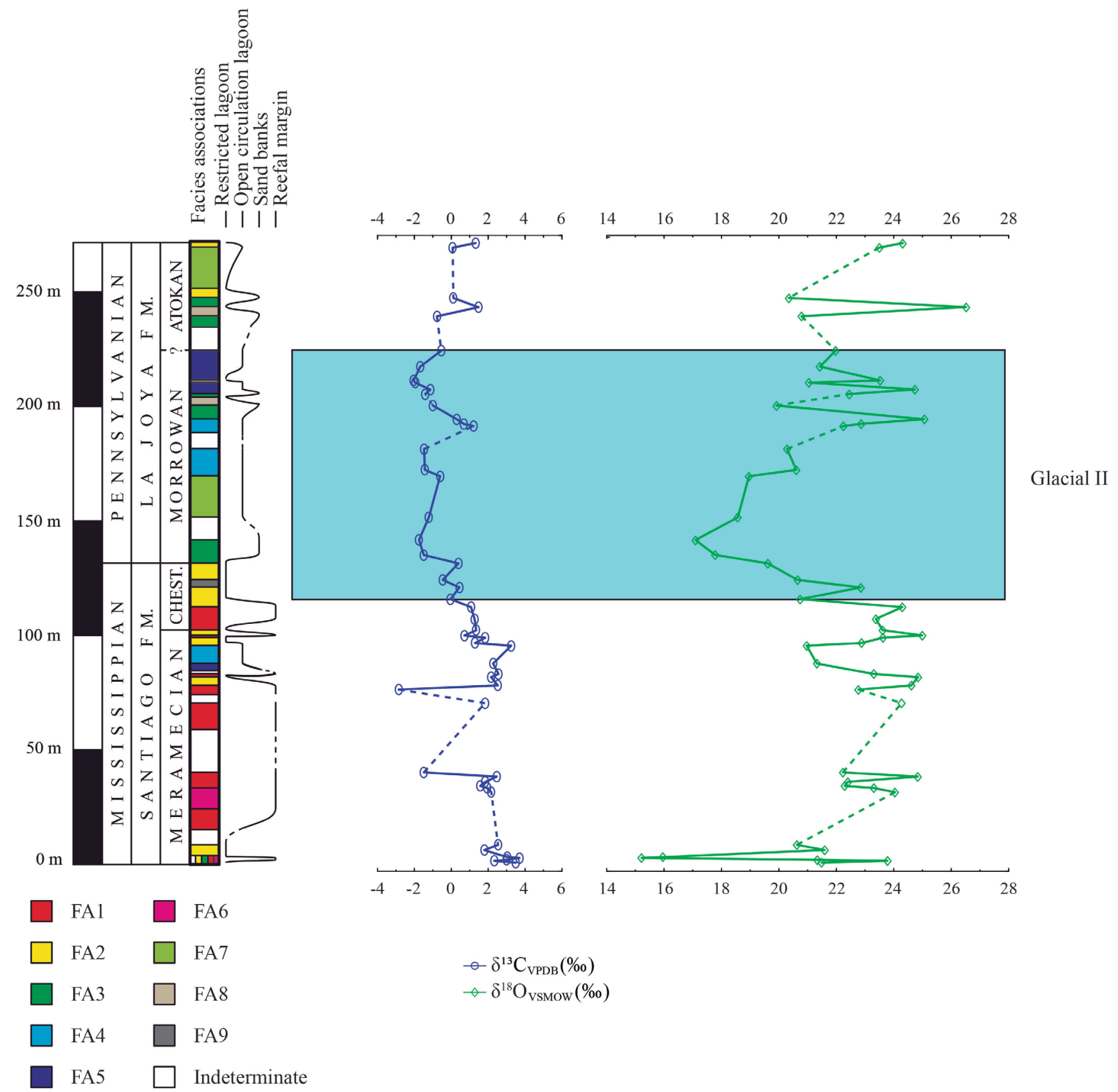

Figure $13 \delta^{18} \mathrm{O}$ and $\delta^{13} \mathrm{C}$ values recorded in samples of the La Joya section compared with the different facies associations, the paleobathymetric curve, as well as the presumable position of Isbell et al. (2003) glacial events. The dash lines indicate strata with diagenesis (dolomitization or silicification) that were not sampled. 
FAl, which is typical of margin platform environments (grain-supported textures with abundant crinoids). At the end of the Meramecian and at the Chesterian, abrupt facies belt and facies zone changes are recorded, along with shallowing sea level. Common facies associations at this interval are FA2 (packstones of pellets) intercalated with FAl and others less abundant like FA4 (wackestone or floatstone of fragmented fossils such as sponges, crinoids, brachiopods, and ostracods) or FA5 (grainstone or rudstone and floatstone with lagoonal fossils), which are typical of nearshore lagoonal environments (either with restricted or open circulation). At the onset of the Morrowan, typical lagoonal associations (FA 7, 4, 5 ) are present with some intercalations of marginal facies (FA3). This means that the changes, previously identified for the latest Meramecian and Chesterian, stopped during most of the Morrowan, when constant shallower lagoon conditions were established in the platform, as can be seen in the paleobathymetric curve. At the end of the Morrowan and during the segment of the Atokan included in the section, some little changes in microfacies are recorded, but with a tendency towards a shallower nearshore restricted platform. This pattern is thought of as a sea level decrease during Early Pennsylvanian that can be correlated with the onset of the glacial event II reported by Isbell et al. (2003), and compared with the positive $\delta^{18} \mathrm{O}$ excursion. Several authors have reported the occurrence of glacial deposits along the Pennsylvanian in outcrops corresponding to Gondwana (Veevers and Powell, 1987; Fielding et al., 2008; Henry et al., 2008; Holz et al., 2008; Martin et al., 2008; Rocha-Campos et al., 2008; among others). During this time, Gondwana underwent various episodes of glaciations that caused important sea level regressions resulting in positive $\delta^{18} \mathrm{O}$ excursions, as more of the ${ }^{16} \mathrm{O}$ was trapped in ice caps during glaciation times (Joachimski et al., 2006).

Another goal of this study is to know the behavior of $\delta^{13} \mathrm{C}$ and $\delta^{18} \mathrm{O}$ isotope values to compare with data from other parts of the world and elucidate a regional or global pattern. Nonetheless, in order to rule out a diagenetic imprint in our samples, a crossplot of $\delta^{18} \mathrm{O}_{\text {vSMOW }}$ against $\delta^{13} \mathrm{C}_{\text {vPDB }}$ values was made (Figure 14). According to some authors (Banner and Hanson, 1990; Titschak et al., 2009; Seuss et al., 2012) a direct covariance of both

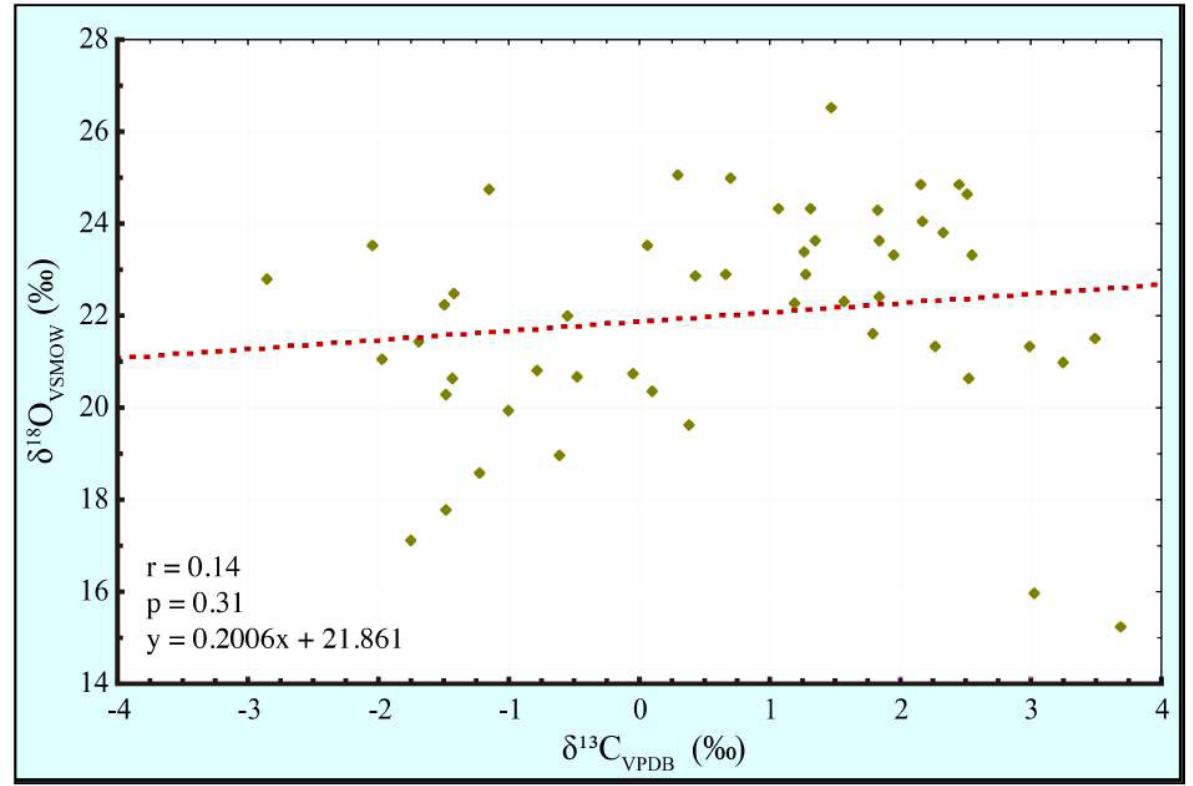

Figure 14 Crossplot of $\delta^{18} \mathrm{O}$ vs $\delta^{13} \mathrm{C}$ showing no direct correlation as evidenced for the almost horizontal regression line (slope of 0.2 ) and the $r$ coefficient indicating a value close to 0 . The p-value of 0.31 supports the lack of correlation between the isotopic values. 
$\delta^{13} \mathrm{C}$ and $\delta^{18} \mathrm{O}$ is evidence of diagenetic alteration affecting both isotopic signatures. However, no covariance is clear from our results, and the resulting correlation coefficient value of 0.14 indicates that there is no correlation between the calculated $\delta^{13} \mathrm{C}$ and $\delta^{18} \mathrm{O}$ values; thus, it is interpreted as no evidence of diagenetic alteration recorded in the isotopic composition.

The $\delta^{18} \mathrm{O}$ signal is more susceptible to diagenetic alteration in bulk rock sampling than $\delta^{13} \mathrm{C}$, and this is reflected in the maximum difference found between the lower and higher $\delta^{18} \mathrm{O}$ values. For $\delta^{18} \mathrm{O}_{\text {vsmow }}$ the maximum value is $26.52 \%$ and the minimum is $15.22 \%$, with a difference of $11.30 \%$, which is wide enough to be considered a reliable proxy of the original seawater composition. However, assuming the samples have been altered evenly, we can infer some patterns. For example, the Meramecian is characterized for several peaks in the $\delta^{18} \mathrm{O}$ signal with relatively high values, except for some lower values at the beginning of the section. These high values could be associated with cooling temperatures, and the peaks, with short time intervals of warming. The evidence in other parts of the world indicate that Meramecian was not a glacial age (Mii et al., 1999; Isbell et al., 2003; Fielding et al., 2008; Frank et al., 2008; among others), as it lies between the Glacial I (Late Devonian-Early Mississippian) and Glacial II events proposed by Isbell et al. (2003), so that the $\delta^{18} \mathrm{O}$ signal would record only a drop in temperatures and not glacial events as such.

At the beginning of the Chesterian, a negative $\delta^{18} \mathrm{O}$ excursion can be drawn that reached its minimum in the lowermost Morrowan. This event could be interpreted as a warming period, with ice cap melt raising ${ }^{16} \mathrm{O}$ in seawater, thus lowering $\delta^{18} \mathrm{O}$. Immediately, we can distinguish an increase that correlate with the global increase that occurred at the onset of the Pennsylvanian and that corresponds to the glacial event II of Isbell et al. (2003). The change in facies association towards nearshore environments confirms a sea-level decrease that might have been caused by this glacial event. The rest of the Morrowan and Atokan is characterized by abrupt changes in the $\delta^{18} \mathrm{O}$ values. Oxygen isotopes are sensitive to many other events besides glacial formation and melting. For example, the amount of fresh water coming into the marine platform can modify $\delta^{18} \mathrm{O}$, because continental runoff is enriched in ${ }^{16} \mathrm{O}$ relative to ocean water, and ultimately this would cause a $\delta^{18} \mathrm{O}$ drop in ocean water. This also affects salinity as freshwater runoff $\left({ }^{16} \mathrm{O}\right.$ enriched) reaching the sea, lowers seawater salinity and hence, ${ }^{18} \mathrm{O}$ levels (Joachimski et al., 2006). However, these authors consider that salinity does not account for much of $\delta^{18} \mathrm{O}$ variation in low-latitude surface waters, as it does surface water temperature and ice volume. Because the microfacies analysis assumes environments close to the shoreline, the influence of continental fresh water is presumed to be important, leading to a local or regional variation in $\delta^{13} \mathrm{C}$ and $\delta^{18} \mathrm{O}$ values.

For the $\delta^{13} \mathrm{C}$ isotope curve, we compared our results with those of bulk rock data reported by Saltzman (2005) in the Great Basin, United States. For the Osagean-Meramecian, Saltzman showed $\delta^{13} \mathrm{C}$ values between $1 \%$ and $3 \%$, whereas in the La Joya section, the average is, for the Meramecian, between $2 \%$ and $3 \%$.

The major difference is found during the Pennsylvanian where Saltzman reported $\delta^{13} \mathrm{C}$ values that range between $1 \%$ and $4 \%$ whereas in the La Joya section, values extend from $-2 \%$ to $1.5 \%$, approximately. For the Chesterian stage, the La Joya $\delta^{13} \mathrm{C}$ values approach those reported by Batt et al. (2007) in east-central Idaho, with an overall pattern towards lower values at the end of the Chesterian from $2 \%$ o to slightly lower than $0 \%$. This pattern is also recognized in the Chesterian of La Joya (from $1.3 \%$ to values near $-0.5 \%$ ), but this interval is very short, indicating that only a portion of Batt et al.'s (2007) Chesterian is represented in our section.

At the beginning of the Morrowan (Pennsylvanian), this tendency disappears, since there is no evidence of the typical positive $\delta^{13} \mathrm{C}$ excursion 
reported by many authors in several localities across the world (Mii et al., 1999, 2001; Saltzman, 2005; Batt et al., 2007; Frank et al., 2008; among others). We notice a slight positive excursion well into the Morrowan but not at its onset. The $\delta^{18} \mathrm{O}$ curve also shows a positive excursion, but it starts slightly after the onset of the Morrowan.

This excursion does not match with that reported in the literature showing its onset at the beginning of the Morrowan (Bashkirian), leading to the conclusion that this excursion is due to a more regional pattern, rather than global. Perhaps, a more exhaustive study in this interval is necessary to elucidate the global pattern.

For some authors (Lowenstam, 1961; Grossman et al., 1996), geochemical composition of brachiopod shell calcite is a reliable proxy for paleoenvironmental reconstruction. This assertion was based on the idea that brachiopods precipitate their shells in isotopic equilibrium with seawater. Since they have a low- $\mathrm{Mg}$ calcite composition, they are less susceptible to diagenetic alteration in comparison with the aragonite and/or high-Mg calcite composition of other biogenic components in the matrix (Batt et al., 2007). In contrast to this assumption, some studies revealed that brachiopod shells are not always in isotopic equilibrium with ambient seawater, as vital effects change the carbon and oxygen isotope composition (Carpenter and Lohman, 1995; Brand et al., 2015). Therefore, some corrections (Mg-effect) and cautions (avoiding fast-growing areas) to properly interpret the original seawater composition are needed (Brand et al., 2015). This fractionation chiefly depends on what area of the shell is chosen for analysis (primary or secondary layer; Carpenter and Lohman, 1995). Furthermore, some studies demonstrated that bulk carbonates have a continuous and facies-independent record, and therefore they are excellent proxies of seawater $\delta^{13} \mathrm{C}$ composition (Weissert et al., 1985; Saltzman, 2003; Batt et al., 2007; Liu et al., 2017). For these reasons, and the scarcity of a continuous record of well-preserved brachiopod shells in the study area, a total rock isotopic analysis is used.
Some of the discrepancies observed between this work and others could be assigned to regional or local controls that mask global patterns. In addition to diagenetic overprint, tectonic influences, local changes in productivity, or $\mathrm{C}_{\text {org }}$ sequestration, among others, could be mentioned. To reduce the bias caused by diagenesis, the samples were carefully selected avoiding those of high diagenetic alteration (silicification, oxidization, or dolomitization). Furthermore, in the drilling process, we avoided sampling in calcite veins or areas of evident recrystallization (except for grainstone-texture samples that are cemented by sparite).

During the Pennsylvanian, the eastern part of Sonora was in one end of the Pedregosa Basin (Figure 15), a shallow marine platform that divided the North American Craton from the Rheic Ocean (Palafox-Reyes, 2011). Greenwood et al. (1977) included open-shelf rocks of Pennsylvanian age from southeastern Arizona, southwestern New Mexico, and northern Mexico in the extension of the Pedregosa Basin. The shallow facies belts recognized in this study indicate that the La Joya section was part of the shallower area of Pedregosa (Pedregosa shelf according to Armin (1987)). During the Late Paleozoic, some terranes surrounded this basin: the Florida Islands to the northeast, and the Zuni-Defiance uplift and the Sedona arch to the north and northwest.

In the southern part, the basin was bordered by the Marathon-Chihuahua segment of the Ouachita orogeny (Armin, 1987, and references therein). According to this model, we propose that the La Joya section was located in the area corresponding to the Pedregosa platform, and in close vicinity with the deeper Pedregosa Basin, both of them somewhat distant from the continental uplifts, which explains the lack of sufficient input of siliciclastics in the platform.

According to Batt et al. (2007) the differences found in $\delta^{13} \mathrm{C}$ values between Tethyan and Panthalassan brachiopods could be explained by variations across the platform due to differences in residence times of the waters found in restricted platforms, as well as the mixing of water masses isotopically 
different because of upwelling and freshwater influx. The upwelling process had already been proposed as a likely mechanism that accounted for $\delta^{13} \mathrm{C}$ differentiation (Mii et al., 1999, 2001; Saltzman, 2003; Liu et al., 2015). These zones of upwelling would have developed due to the closure of the Rheic seaway during the Middle to Late Visean (Meramecian-Chesterian), which reorga- nized the patterns of ocean circulation and ultimately promoted areas of upwelling in Western Euramerica (Liu et al., 2015). Such differentiation would cause areas in Western Euramerica (Midcontinent U. S.) to have lower $\delta^{13} \mathrm{C}$ values (a shift of only $1.5 \%$ ) with regard to Eastern Euramerica during mid-Carboniferous (a 3\%o increase; Mii et al., 2001). In this context, the lack of a clear pos-
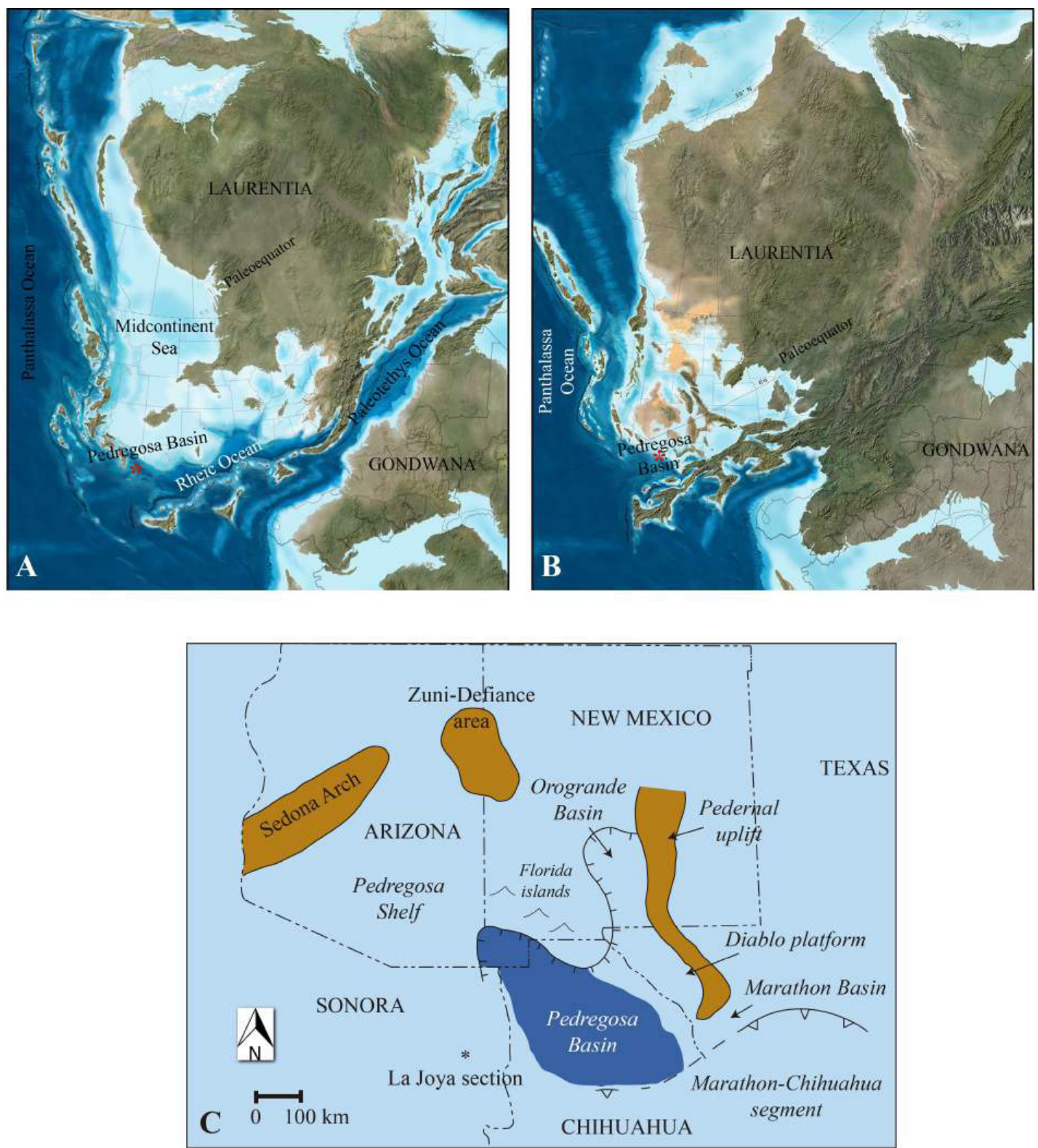

Figure 15 Paleogeographic maps showing the location of the La Joya section (with an asterisk) in the Pedregosa platform of North America during (A) the Early-Middle Mississippian (345 Ma), and (B) the Middle Pennsylvanian (308 Ma). In (C) a reconstruction of tectonic elements present in the late Paleozoic of Sonora. (A) and (B): adapted from Blakey: http://deeptimemaps.com/map-roomindividual/, (C) modified from Armin (1987). 
itive excursion in $\delta^{13} \mathrm{C}$ values for the Morrowan of La Joya can be due to a masking of the global pattern, leading by the occurrence of upwelling that brings ${ }^{12} \mathrm{C}$-enriched nutrients to the sea surface (expressed by lower $\delta^{13} \mathrm{C}$ values). Also, if there were poor water replacement with open seas, and the proximity to land brought sufficient amount of ${ }^{12} \mathrm{C}$-enriched sediments, they could hamper the expression of a clear $\delta^{13} \mathrm{C}$ positive excursion correlated with the onset of the mid-Carboniferous glaciation.

\section{Conclusions}

The microfacies analysis yields 9 facies associations distributed along the $270 \mathrm{~m}$ of the La Joya section in the Mississippian-Pennsylvanian of the Sierra Agua Verde, Sonora. These facies associations span marine paleoenvironments from the marginal reef position up to sand banks and open and restricted lagoons. The paleobathymetric curve constructed after these facies associations indicates deeper conditions during the Meramecian times with abrupt changes during Chesterian and more stable and increasingly shallower waters for the Pennsylvanian, which can be correlated with the onset of glacial II reflected as a global sea-level drop. This decline can be confirmed with a positive excursion in $\delta^{18} \mathrm{O}$ values during the Mississippian-Pennsylvanian boundary, although for the La Joya section, this pattern is shown at the middle of the Morrowan. More studies are necessary to clarify this discrepancy. When we compare our $\delta^{13} \mathrm{C}$ values with literature, some differentiations appear. Input of land ${ }^{12} \mathrm{C}$-enriched fresh water, as well as regional upwelling and long residence times of the seawater in this mostly restricted platform are claimed as causes of the discrepancies.

This work is an approach in the interpretation of paleoenvironmental conditions and more investigation has to be done, particularly with other Sonoran sections, which are poorly studied in a geochemical framework.

\section{Acknowledgements}

The authors wish to thank Matilde Beresi, Francisco Sánchez-Beristain, and Rubén A. López-Doncel for their suggestions that improved significantly this work, as well as MSc Jaime Díaz-Ortega and the Instituto de Geología, UNAM for the technical support. Financial help was provided by CONACYT No. 165826 and ECOS Francia-México No. M13-U01 "Evolución de los Ecosistemas del Paleozoico de México." RVO thanks Posgrado en Ciencias Biológicas, UNAM, for the academic support.

\section{References}

Almazán-Vázquez, E., Vachard, D., BuitrónSánchez, B.E., Mendoza, G., GómezEspinosa, C., 2007, The late Atokan (Moscovian-Pennsylvanian) chaetetid accumulations of Sierra Agua Verde, Sonora (NW Mexico): composition, facies and paleoenvironmental signals, in Álvaro, J.J., Aretz, M., Boulvain, F., Munnecke, A., Vachard, D., Venin, E. (eds.), Palaeozoic Reefs and Bioaccumulations: Climatic and Evolutionary Controls: London, Geological Society of London, Special Publications, 275, 189-200.

Armin, R.A., 1987, Sedimentology and tectonic significance of Wolfcampian (Lower Permian) conglomerates in the Pedregosa basin: Southeastern Arizona, southwestern New Mexico, and northern Mexico: Geological Society of America Bulletin, 99 (1), 42-65. https://doi. org/10.1130/0016-7606(1987)99<42:satso $\mathrm{w}>2.0 . \mathrm{co} ; 2$

Banner, J.L., Hanson, G.N., 1990, Calculation of simultaneous isotopic and trace element variations during water-rock interaction with applications to carbonate diagenesis: Geochimica et Cosmochimica Acta, 54 (11), 3123-3137. https://doi. org/10.1016/0016-7037(90)90128-8 
Batt, L.S., Montañez, I.P., Isaacson, P., Pope, M.C., Butts, S.H., Abplanalp, J., 2007, Multi-carbonate component reconstruction of mid-carboniferous (Chesterian) seawater 813C: Palaeogeography, Palaeoclimatology, Palaeoecology, 256 (3-4), 298-318. https:// doi.org/10.1016/j.palaeo.2007.02.049

Brand, U., 1989, Global climatic changes during the Devonian-Mississippian; stable isotope biogeochemistry of brachiopods: Global and Planetary Change, 75(4), 311-329. https:// doi.org/10.1016/0031-0182(89)90192-2

Brand, U., Azmy, K., Griesshaber, E., Bitner, M.A., Logan, A., Zuschin, M., Ruggiero, E., Colin, P.L., 2015, Carbon isotope composition in modern brachiopod calcite: A case of equilibrium with seawater?: Chemical Geology, 411, 81-96. https://doi. org/10.1016/j.chemgeo.2015.06.021

Buitrón-Sánchez, B.E., Gómez-Espinosa, C., Almazán-Vázquez, E., Vachard, D., 2007, A late Atokan regional encrinite (early late Moscovian, Middle Pennsylvanian) in the Sierra Agua Verde, Sonora state, NW Mexico, in Álvaro, J.J., Aretz, M., Boulvain, F., Munnecke, A., Vachard, D., Venin, E. (eds.), Palaeozoic Reefs and Bioaccumulations: Climatic and Evolutionary Controls: London, Geological Society of London, Special Publications, 275, 201-209.

Carpenter, S.J., Lohmann, K.C., 1995, $\delta 180$ and $\delta 13 \mathrm{C}$ values of modern brachiopod shells: Geochimica et Cosmochimica Acta, 59(18), 3749-3764. https://doi. org/10.1016/0016-7037(95)00291-7

Coplen, T.B., 1988, Normalization of oxygen and hydrogen isotope data: Chemical Geology (Isotope Geoscience Section), 72(4), 293-297. https://doi. org/10.1016/0168-9622(88)90042-5

Coplen, T.B., Brand, W.A., Gehre, M., Gröning, M., Harro, A.J.M., Toman B., Verkouteren, R.M., 2006, New guidelines for $\delta 13 \mathrm{C}$ measurements: Analytical Chemistry, 78, 2439-2441.
Coronado, I., Rodríguez, S., 2009, Análisis de microfacies de los montículos de la Formación Cosgaya. Sección de Las Ilces, Pensilvánico, Cantabria: Coloquios de Paleontología, 59, 61-91.

Dunham, R.J., 1962, Classification of carbonate rocks according to depositional texture, in Ham, W.E. (ed.), Classification of carbonate rocks: American Association of Petroleum Geologists 1, 108-1212.

Ekdale, A.A., Ekdale, S.F., Wilson, J.L., 1976, Numerical analysis of carbonate microfacies in the Cupido Limestone (NeocomianAptian), Coahuila, Mexico: Journal of Sedimentary Petrology, 46, 362-368. https://doi.org/10.1306/212f6f64-2b24$11 \mathrm{~d} 7-8648000102 \mathrm{c} 1865 \mathrm{~d}$

Fielding, G.R., Frank, T.D., Isbell, J.L., 2008, The late Paleozoic ice age - A review of current understanding and synthesis of global climate patterns, in Fielding, G.R., Frank, T.D., and Isbell, J.L. (eds.), Resolving the Late Paleozoic Ice Age in Time and Space: Geological Society of America Special Paper 441, 343-354.

Flügel, E., 1972, Mikrofazielle Untersuchungen in der alpinen Trias: Methoden und Probleme: Mitteilungen der Gesellschaft der Geologieund Bergbaustudenten in Österreich, 21, 6-64.

Flügel, E., 2010, Microfacies of carbonate rocks. Analysis, interpretation and application: London New York, Springer, 984 p.

Frank, T.D., Birgenheier, L.P., Montañez, I.P., Fielding, C.R., 2008, Late Paleozoic climate dynamics revealed by comparison of iceproximal stratigraphic and ice-distal isotopic records, in Fielding, C.R., Frank, T.D., Isbell, J.L. (eds.), Resolving the Late Paleozoic Ice Age in Time and Space: Geological Society of America, Special Paper 441, 1-12.

Gehrels, G.E., Dickinson, W.R., Ross, G.M., Stewart, J.H., Howell, D.G., 1995, Detrital zircon reference for Cambrian to Triassic miogeoclinal strata of western North America: Geology, 23, 831-834. 
Gómez-Espinosa, G., 2010, Análisis tafonómico y taxonomía del macrobentos calcáreo del Paleozoico Tardío de Sierra Agua Verde, noreste de Sonora, México: México, Universidad Nacional Autónoma de México, $\mathrm{PhD}$ dissertation, $141 \mathrm{p}$.

Gómez-Espinosa, G., Vachard. D., BuitrónSánchez, B.E., Almazán-Vázquez, E., Mendoza-Madera, C., 2008, Pennsylvanian fusulinids and calcareous algae from Sonora (northwestern Mexico), and their biostratigraphic and palaeobiogeographic implications: Comptes Reendus Palevol, 7(5), 259-268. https://doi.org/10.1016/j. crpv.2008.04.001

Greenwood, E., Kottlowski, F.E., Thompson, S., III, 1977, Petroleum potential and stratigraphy of Pedregosa basin: Comparison with Permian and Orogrande basins: American Association of Petroleum Geologists Bulletin, 61, 1448-1469. https://doi.org/10.1306/ clea45ae-16c9-11d7-8645000102c1865d

Grossman,E.L., Mii,H.-S., Zhang, C., Yancey, T.E., 1996, Ghemical variation in Pennsylvanian brachiopod shells - diagenetic, taxonomic, microstructural, and seasonal effects: Journal of Sedimentary Research, 66, 1011-1022. https://doi.org/10.1306/ d4268469-2b26-11d7-8648000102c1865d

Henry, L.G., Isbell, J.L., Limarino, G.O., 2008, Carboniferous glacigenic deposits of the proto-Precordillera of west-central Argentina, in Fielding, C.R., Frank, T.D., Isbell, J.L. (eds.), Resolving the Late Paleozoic Ice Age in Time and Space: Geological Society of America, Special Paper 441, 131-142.

Holz, M., Souza, P.A., Iannuzzi, R., 2008, Sequence stratigraphy and biostratigraphy of the Late Carboniferous to Early Permian glacial succession (Itararé subgroup) at the eastern-southeastern margin of the Paraná Basin, Brazil, in Fielding, G.R., Frank, T.D., Isbell, J.L. (eds.), Resolving the Late Paleozoic Ice Age in Time and Space: Geological Society of America, Special Paper 441, 115-129.
Isbell, J.L., Miller, M.F., Wolfe, K.L., Lenaker, P.A., 2003, Timing of late Paleozoic glaciation in Gondwana: Was glaciation responsible for the development of northern hemisphere cyclothems? in M. A. Chan, A. W. Archer (eds.), Extreme depositional environments: mega end members in geologic time: Geological Society of America, Special Paper 370, 5-24. https:// doi.org/10.1130/0-8137-2370-1.5

Joachimski, M.M., von Bitter, P.H., Buggisch, W., 2006, Constraints on Pennsylvanian glacioeustatic sea-level changes using oxygen isotopes of conodont apatite: Geology, 34(4), 277-280. https://doi.org/10.1130/ g22198.1

Kietzmann, D.A., Palma, R.M., Bressan, G.S., 2008, Facies y microfacies de la Rampa Tithoniana-Berriasiana de la Cuenca Neuquina (Formación Vaca Muerta) en la sección del Arroyo Loncoche-Malargüe, Provincia de Mendoza: Revista de la Asociación Argentina, 63, 696-713.

Liu, C., Jarochowska, E., Du, Y., Vachard, D., Munnecke, A., 2015, Microfacies and carbon isotope records of Mississippian carbonates from the isolated Bama Platform of Youjiang Basin, South China: Possible responses to climate-driven upwelling: Palaeogeography, Palaeoclimatology, Palaeoecology, 438, 96-112. https://doi.org/10.1016/j. palaeo.2015.07.048

Liu, G., Jarochowska, E., Yuansheng, D., Vachard, D., Munnecke, A., 2017, Stratigraphical and $813 \mathrm{C}$ records of Permo-Carboniferous platform carbonates, South China: Responses to late Paleozoic icehouse climate and icehouse-greenhouse transition: Palaeogeography, Palaeoclimatology, Palaeoecology, 474, 113-129. https://doi. org/10.1016/j.palaeo.2016.07.038

Lowenstam, H., 1961, Mineralogy, O18/O16 ratios, and strontium and magnesium contents of recent and fossil brachiopods and their bearing on the history of the oceans: Journal of the Geological Society (London), 147, 1-4. https://doi.org/10.1086/626740 
Martin, J.R., Redfern, J., Aitken, J.F., 2008, A regional overview of the late Paleozoic glaciation in Oman, in Fielding, G.R., Frank, T.D., Isbell, J.L. (eds.), Resolving the Late Paleozoic Ice Age in Time and Space: Geological Society of America, Special Paper 441, 175-186. https://doi. org/10.1130/978-0-8137-2441-6

McCrea, J.M., 1950, On the isotopic chemistry of carbonates and a paleotemperature scale: The Journal of Chemical Physics, 18(6), 849857. https://doi.org/10.1063/1.1747785

Mii, H., Grossman E.L., Yancey, T.E., 1999, Carboniferous isotope stratigraphies of North America: Implications for Carboniferous paleoceanography and Mississippian glaciation: Geological Society of America Bulletin, 111(7), 960-973. https://doi. org/10.1130/0016-7606(1999)111<0960:cis ona $>2.3 . \operatorname{co} ; 2$

Mii, H., Grossman, E.L., Yancey, T.E., Chuvashov, B., Egorov, A., 2001, Isotopic records of brachiopod shells from the Russian Platform - evidence for the onset of mid- Carboniferous glaciation: Chemical Geology, 175(1-2), 133-147. https://doi. org/10.1016/s0009-2541(00)00366-1

Minjarez-Sosa, I., Ochoa-Granillo, J.A., SosaLeón, P., 1993, Geología de la Sierra Agua Verde, NE de Villa Pesqueira (Matape) (abstract), in Tercer Simposio de la Geología de Sonora y Áreas Adyacentes: Hermosillo, Sonora, México, González-León, G., VegaGranillo, E.L. (eds.), 83-85.

Navas-Parejo, P., Palafox, J.J., Villanueva, R., Buitrón-Sánchez, B.E., Valencia-Moreno, M., 2017, Mid-Carboniferous shallowwater conodonts from northwest Mexico: Micropaleontology, 63(6), 383-402.

Ochoa-Granillo, J.A., Sosa-León, J.P., 1993, Geología y estratigrafía de la Sierra Agua Verde con énfasis en el Paleozoico: Hermosillo, Sonora, México, Universidad de Sonora, Bachelor dissertation, 59 p.
Palafox-Reyes, J.J., 2011, Du Craton au Rheïque: le nord et le centre de l'état du Sonora (Mexique) au Paleozoïque Superieur (Devonien-Pennsylvanien), lithostratigraphie, biostratigraphie, aproche geochimique et implications geologiques: Lille, France, Université de Lille 1, PhD dissertationt, 318 p. Poole, F.G., Stewart, L.H., Repetski, J.E., Harris, A.G., Ross, R.J.Jr., Ketner, K.B., AmayaMartínez, R., Morales-Ramírez, J.M., 1995, Ordovician carbonate-shelf rocks of Sonora, Mexico, in Cooper, J.D., Droser, M.L., Finney, S.C. (eds.), Ordovician Odyssey: Short Papers for the Seventh International Symposium on the Ordovician System: Las Vegas, Nevada, Society of Economic Paleontologists and Mineralogists, Pacific Section, Book No. 77, 267-275.

Repetski, J.E., Harris, A.G., Stewart, J.H., Poole, F.G., Morales-Ramírez, J.M., 1985, Early Ordovician conodonts from central Sonora, Mexico (abstract), in Fourth European Conodont Symposium (ECOS IV): Nothingham, U.K., 25-26.

Rocha-Campos, A.C., dos Santos, P.R., Canuto, J.R., 2008, Late Paleozoic glacial deposits of Brazil: Paraná Basin, in Fielding, C.R., Frank, T.D., Isbell, J.L. (eds.), Resolving the Late Paleozoic Ice Age in Time and Space: Geological Society of America, Special Paper 441, 97-114.

Saltzman, M.R., 2003, Late Paleozoic Ice Age: Oceanic gateway or $\mathrm{pCO}_{2}$ ?: Geology, 31 (2), 151-154. https://doi.org/10.1130/00917613(2003)031\%3C0151:lpiaog\%3E2.0. co;2

Saltzman, M.R., 2005, Phosphorous, nitrogen, and the redox evolution of the Paleozoic oceans: Geology, 33(7), 573-576. https:// doi.org/10.1130/g21535.1

Schlager, W., 2002, Sedimentology and sequence stratigraphy of carbonate rocks: Amsterdam (Vrije Universiteit/Earth and Life Sciences), $146 \mathrm{p}$. 
Seuss, B., Titschack, J., Seifert, S., Neubauer, J., Nützel, A., 2012, Oxygen and stable carbon isotopes from a nautiloid from the middle Pennsylvanian (Late Carboniferous) impregnation Lagerstätte 'Buckhorn Asphalt Quarry' - Primary paleo-environmental signals versus diagenesis: Palaeogeography, Palaeoclimatology, Palaeoecology, 319320, 1-15. https://doi.org/10.1016/j. palaeo.2011.12.008

Stewart, J.H., McMenamin, M.A.S., MoralesRamírez, J.M., 1984, Upper Proterozoic and Cambrian rocks in the Caborca region, Sonora, Mexico-physical stratigraphy, biostratigraphy, paleocurrent studies, and regional relations: U.S. Geological Survey Professional Paper 1309, 1-36.

Stewart, J.H., Madrid, R.J., Poole, F.G., Ketner, K.B., 1988, Studies of Late Proterozoic, Paleozoic, and Triassic rocks in Sonora, Mexico (abstract), in Segundo Simposio sobre Geología y Minería de Sonora: Hermosillo, Sonora, México, Almazán-Vázquez, E., Fernández-Aguirre, M.A. (eds.), 60-62.

Stewart, J.H., Poole, F.G., Harris, A.G., Repetsky, J.E., Wardlaw, B.R., Mamet, B.L., MoralesRamírez, J.M., 1999, Neoproterozoic(?) to Pennsylvanian inner-shelf, miogeoclinal strata in Sierra Agua Verde, Sonora, Mexico: Revista Mexicana de Ciencias Geológicas, $16,35-62$.
Titschak, J., Radtke, U., Freiwald, A., 2009, Dating and characterisation of polymorphic transformation of aragonite to calcite in Pleistocene bivalves from Rhodes (Greece) by combined shell microstructure, stable isotope, and electron spin resonance study. Journal of Sedimentary Research, 79(5), 322-346. https://doi.org/10.2110/jsr.2009.037

Veevers, J.J., Powell, C.M., 1987, Late Paleozoic glacial episodes in Gondwanaland reflected in transgressive-regressive depositional sequences in Euramerica: Geological Society of America Bulletin, 98(4), 475-487. https:// doi.org/10.1130/0016-7606(1987)98<475:lpg eig $>2.0 . c 0 ; 2$

Veizer, J., Ala, D., Azmy, K., Bruckschen, P., Buhl, D., Bruhn, F., Carden, G.A.F., Diener, A., Ebneth, S., Godderis, Y., Jasper, T., Korte, C., Pawellek, F., Podlaha, O.G., Strauss, H., 1999, 87Sr/86Sr, $813 \mathrm{C}$ and $\delta 18 \mathrm{O}$ evolution of Phanerozoic seawater in Earth system evolution: Chemical Geology, 161 (1-3), 59-88. https://doi.org/10.1016/ s0009-2541(99)00081-9

Weissert, H.J., McKenzie, J.A., Channell, J.E.T., 1985, Natural variations in the carbon cycle during the Early Cretaceous: Geophysical Monograph, 32, 531-545. https://doi. org/10.1029/gm032p0531

Wilson, J.L., 1975, Carbonate facies in geologic history: Berlin, Springer, $471 \mathrm{p}$. 


\section{Appendix}

Table 1. $\delta^{13} \mathrm{C}$ and $\delta^{8} \mathrm{O}$ values of the La Joya section, Sierra Agua Verde, Sonora, Mexico relative to VPDB and VSMOW scales.

\begin{tabular}{|c|c|c|c|}
\hline Sample & $\delta^{13} \mathrm{C}_{\mathrm{VPDB}}(\% \mathrm{o})$ & $\begin{array}{c}\delta^{18} \mathrm{O}_{\mathrm{VPDB}} \\
(\%)\end{array}$ & $\begin{array}{c}\delta^{18} \mathrm{O}_{\text {VSMOW }} \\
(\% \text { ) }\end{array}$ \\
\hline LJ 2 & 3.5 & -9.14 & 21.49 \\
\hline LJ 3 & 2.33 & -6.92 & 23.78 \\
\hline LJ 4 & 3 & -9.29 & 21.33 \\
\hline LJ 5 & 3.69 & -15.22 & 15.22 \\
\hline LJ 6 & 3.03 & -14.5 & 15.96 \\
\hline LJ 7 & 1.79 & -9.04 & 21.59 \\
\hline LJ 8 & 2.53 & -9.97 & 20.63 \\
\hline LJ 11 & 2.17 & -6.66 & 24.04 \\
\hline LJ 12 & 1.95 & -7.38 & 23.31 \\
\hline LJ 13 & 1.57 & -8.36 & 22.29 \\
\hline LJ 14 & 1.84 & -8.25 & 22.4 \\
\hline LJ 15 & 2.46 & -5.89 & 24.83 \\
\hline LJ 16 & -1.49 & -8.42 & 22.23 \\
\hline LJ 21 & 1.83 & -6.43 & 24.28 \\
\hline LJ 24 & -2.85 & -7.89 & 22.77 \\
\hline LJ 25 & 2.52 & -6.11 & 24.61 \\
\hline LJ 26 & 2.16 & -5.88 & 24.85 \\
\hline LJ 27 & 2.56 & -7.38 & 23.3 \\
\hline LJ 29 & 2.27 & -9.3 & 21.32 \\
\hline LJ 30 & 3.25 & -9.64 & 20.97 \\
\hline LJ 31 & 1.28 & -7.79 & 22.88 \\
\hline LJ 32 & 1.84 & -7.07 & 23.62 \\
\hline LJ 33 & 0.71 & -5.75 & 24.99 \\
\hline LJ 34 & 1.35 & -7.08 & 23.61 \\
\hline LJ 35 & 1.27 & -7.31 & 23.38 \\
\hline LJ 36 & 1.07 & -6.41 & 24.3 \\
\hline LJ 37 & -0.04 & -9.86 & 20.74 \\
\hline LJ 38 & 0.44 & -7.81 & 22.86 \\
\hline LJ 39 & -0.47 & -9.96 & 20.65 \\
\hline $\mathrm{LJ} 40$ & 0.39 & -10.96 & 19.61 \\
\hline LJ 41 & -1.48 & -12.73 & 17.78 \\
\hline LJ 42 & -1.75 & -13.4 & 17.09 \\
\hline LJ 43B & -1.22 & -11.97 & 18.57 \\
\hline LJ 44 & -0.61 & -11.59 & 18.96 \\
\hline LJ 44B & -1.43 & -10 & 20.61 \\
\hline LJ 45 & -1.47 & -10.31 & 20.28 \\
\hline LJ 47 & 1.2 & -8.4 & 22.25 \\
\hline LJ 48 & 0.67 & -7.8 & 22.87 \\
\hline LJ 49 & 0.3 & -5.67 & 25.06 \\
\hline LJ 50 & -1 & -10.67 & 19.91 \\
\hline LJ 52 & -1.41 & -8.21 & 22.45 \\
\hline LJ 53 & -1.14 & -5.99 & 24.74 \\
\hline LJ 54 & -1.96 & -9.57 & 21.05 \\
\hline LJ 55 & -2.04 & -7.17 & 23.52 \\
\hline LJ 56 & -1.68 & -9.2 & 21.43 \\
\hline LJ 57 & -0.54 & -8.66 & 21.98 \\
\hline LJ 59 & -0.78 & -9.82 & 20.79 \\
\hline LJ 60 & 1.48 & -4.26 & 26.52 \\
\hline LJ 61 & 0.11 & -10.25 & 20.34 \\
\hline LJ 63 & 0.07 & -7.19 & 23.5 \\
\hline LJ 64 & 1.32 & -6.4 & 24.31 \\
\hline
\end{tabular}

